\title{
The contribution of thymic tolerance to central nervous system autoimmunity
}

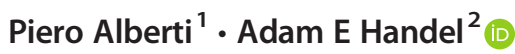 \\ Received: 28 August 2020 / Accepted: 9 October 2020 / Published online: 27 October 2020 \\ (C) The Author(s) 2020
}

\begin{abstract}
Autoimmune diseases of the central nervous system (CNS) are associated with high levels of morbidity and economic cost. Research efforts have previously focused on the contribution of the peripheral adaptive and innate immune systems to CNS autoimmunity. However, a failure of thymic negative selection is a necessary step in CNS-reactive T cells escaping into the periphery. Even with defective thymic or peripheral tolerance, the development of CNS inflammation is rare. The reasons underlying this are currently poorly understood. In this review, we examine evidence implicating thymic selection in the pathogenesis of CNS autoimmunity. Animal models suggest that thymic negative selection is an important factor in determining susceptibility to and severity of CNS inflammation. There are indirect clinical data that suggest thymic function is also important in human CNS autoimmune diseases. Specifically, the association between thymoma and paraneoplastic encephalitis and changes in $\mathrm{T}$ cell receptor excision circles in multiple sclerosis implicate thymic tolerance in these diseases. We identify potential associations between CNS autoimmunity susceptibility factors and thymic tolerance. The therapeutic manipulation of thymopoiesis has the potential to open up new treatment modalities, but a better understanding of thymic tolerance in CNS autoimmunity is required before this can be realised.
\end{abstract}

\section{Introduction}

Autoimmune disorders that affect the central nervous system (CNS) are an important cause of neurological morbidity and mortality and are associated with major economic cost [1]. The most prevalent and extensively studied of CNS autoimmune diseases is multiple sclerosis (MS), which affects $\sim 2.3$ million people globally with prevalence of $\sim 1$ in 1000 individuals in Western countries [2]. The total economic burden of MS was estimated as $€ 14.6$ billion in Europe [3]. Other CNS autoimmune conditions are divided into CNS-specific inflammatory disorders (Table 1) or systemic inflammatory disorders with

This article is a contribution to the special issue on: The thymus and autoimmunity - Guest Editor: Georg Holländer

Adam E Handel

adam.handel@ndcn.ox.ac.uk

Piero Alberti

piero.alberti@wadham.ox.ac.uk

Wadham College, University of Oxford, Oxford OX1 3PN, UK

2 Nuffield Department of Clinical Neurosciences, University of Oxford, Oxford OX3 9DU, UK
CNS manifestations due to direct reaction against CNS parenchyma or CNS vasculitis.

CNS inflammation is the result of pathological dysfunction in immune tolerance, which in turn implies failure in two mechanisms which ensure that adaptive immunity recognises and responds to pathogen-associated non-self-antigens while remaining tolerant of autoantigens. Immunopathology of CNS autoimmune disorders involves breaking of tolerance in both the $\mathrm{T}$ and $\mathrm{B}$ cell compartments: CNSdirected autoreactive $\mathrm{B}$ cells, $\mathrm{CD}^{+} \mathrm{T}$ cells and $\mathrm{CD} 4^{+}$ helper $\mathrm{T}$ cells $\left(\mathrm{T}_{\mathrm{H}} 1, \mathrm{~T}_{\mathrm{H}} 17\right)$ infiltrate the CNS along with innate immune cells leading to neurotoxicity and/or inflammatory tissue injury [4] (Fig. 1).

Tolerance in the $\mathrm{T}$ cell compartment is maintained by its continuous induction both centrally in the thymus and peripherally in target tissues $[5,6]$. These mechanisms shape the repertoire of antigens recognised by $\mathrm{T}$ cells via their $\mathrm{T}$ cell receptors (TCR). Therefore, the nature and severity of defects in central and peripheral tolerance mechanisms determine the extent and diversity of the spectrum of autoantigens characterising different CNS autoimmune diseases [7]. B cell tolerance is established by sequential checkpoints in both early and late stages of $\mathrm{B}$ cell differentiation in bone marrow $[8,9]$. While this central $\mathrm{B}$ cell tolerance develops 
independently of $\mathrm{T}$ cell modulation, autoreactive B cells escaping negative selection in bone marrow or generated in the periphery as a result of somatic hypermutation are normally prevented from causing autoimmunity via B-T cell interaction, most importantly induction of $\mathrm{B}$ cell anergy or FoxP $3^{+}$ regulatory $\mathrm{T}$ cells $\left(\mathrm{T}_{\text {reg }}\right)[10,11]$.

Experimental and clinical studies on the role of immune tolerance in the onset and progression of CNS autoimmunity have predominantly focused on mechanisms underpinning establishment and long-term maintenance of peripheral tolerance [12]. Historically, the contribution of thymic tolerance mechanisms in both the emergence and continuance of CNS inflammation has not been as extensively studied. However, mounting in vitro and in vivo evidence has reignited interest in mechanisms of central tolerance, particularly thymic selection, in the pathogenesis of CNS autoimmune diseases [13].

In this article, we review current models of the molecular and cellular mechanisms of thymic central tolerance and their role in CNS autoimmunity, review current preclinical and clinical evidence for involvement of thymic dysfunction in CNS autoimmunity and finally consider the potential for therapeutic monitoring and targeting of central tolerance as an avenue to develop novel treatments for patients suffering from MS and other autoimmune CNS diseases.

\section{Thymic development and function}

The thymus develops as part of the segmentation of the posterior pharynx: all TECs originate from the ventral endodermal lining of the third pharyngeal pouch. This primordial thymic anlage attracts early thymocytes and develops into distinct cortical and medullary regions where the interaction of TECs with other local antigen presenting cells (APCs) and stromal cells forms a complex 3D scaffold crucial to thymocyte differentiation and selection [14].

Differentiation, functional specialisation and establishment of tolerance of developing $\mathrm{T}$ cells (thymocytes) depend on their interaction with thymic epithelial cells (TECs) (Fig. 2a). TECs are MHC-expressing antigen-presenting cells (APCs) whose interaction with thymocytes restricts the T cell repertoire to conventional $\alpha \beta$ T cells expressing TCRs which functionally engage self-MHC (positive selection) without leading to autoreactivity (negative selection) [15]. Additionally, growth factor and cytokine signalling by TECs supports thymopoiesis and influences thymocyte lineage specification $[16,17]$.

As well as conventional $\alpha \beta \mathrm{T}$ cells, the thymus also produces $\gamma \delta \mathrm{T}$ cells, natural killer T (NKT) cells and mucosal-associated invariant $\mathrm{T}$ cells. These are not

Table 1 CNS-specific autoimmune diseases

\begin{tabular}{|c|c|c|c|}
\hline Condition & Main antigens & Cellular pathogenesis & Clinical manifestations \\
\hline Multiple sclerosis (MS) & $\begin{array}{l}\text { Multiple possible antigens, } \\
\text { likely myelin components }\end{array}$ & $\begin{array}{l}\text { Combined B cell-mediated } \\
\text { and T cell-mediated inflammation } \\
\text { with innate immunity } \\
\text { contribution }\end{array}$ & $\begin{array}{l}\text { Multifocal CNS relapsing-remitting } \\
\text { inflammatory disease; progressive } \\
\text { neurological deficits associated } \\
\text { with inflammation in progressive } \\
\text { disease MS }\end{array}$ \\
\hline $\begin{array}{l}\text { Neuromyelitis optica } \\
\text { spectrum disorders } \\
\text { (NMOSD) }\end{array}$ & $\begin{array}{l}\text { Aquaporin } 4 \text {, myelin } \\
\text { oligodendrocyte glycoprotein }\end{array}$ & Autoantibody-mediated & $\begin{array}{l}\text { Mono-/polyphasic inflammatory } \\
\text { disease, mainly restricted to } \\
\text { spinal cord or optic nerves }\end{array}$ \\
\hline Autoimmune encephalitis & $\begin{array}{l}\text { Multiple (NMDAR, LGI1, } \\
\text { CASPR2, AMPAR, } \\
\text { GABA }_{\mathrm{A} / \mathrm{B}} \mathrm{R} \text { and others) }\end{array}$ & Autoantibody-mediated & $\begin{array}{l}\text { Variable; typically involves subacute } \\
\text { encephalopathy and seizures }\end{array}$ \\
\hline $\begin{array}{l}\text { Stiff person spectrum } \\
\text { disorder (SPSD) }\end{array}$ & GAD, glycine receptor & $\begin{array}{l}\text { Combined B cell and T cell } \\
\text { involvement }+/- \text { anti-GAD } \\
\text { antibodies }\end{array}$ & Spasms plus muscle rigidity \\
\hline Rasmussen encephalitis & Unknown & $\begin{array}{l}\mathrm{T} \text { cell inflammation plus } \\
\text { innate immunity }\end{array}$ & $\begin{array}{l}\text { Progressive hemiplegia, } \\
\text { pharmacoresistant focal epilepsy } \\
\text { with cognitive decline }\end{array}$ \\
\hline Cerebellitis & GAD, CASPR2, Yo & Variable (B and T cell) & $\begin{array}{l}\text { Subacute onset of ataxia plus other } \\
\text { clinical features }\end{array}$ \\
\hline Bickerstaff encephalitis & Gangliosides (GQ1b) & Autoantibody-mediated & Brainstem deficits \\
\hline CLIPPERS & Unknown & Likely T cell & $\begin{array}{l}\text { Brainstem deficits responsive } \\
\text { to steroids }\end{array}$ \\
\hline $\begin{array}{l}\text { Combined central and } \\
\text { peripheral demyelination }\end{array}$ & Neurofascin & Autoantibody-mediated & $\begin{array}{l}\text { Focal CNS neurological deficits } \\
\text { plus polyradiculoneuropathy }\end{array}$ \\
\hline
\end{tabular}

NMDAR, $N$-methyl-D-aspartate receptor; LGI1, leucine-rich glioma-Inactivated protein 1; CASPR2, contactin-associated protein-like 2; AMPAR, $\alpha$ amino-3-hydroxy-5-methyl-4-isoxazolepropionic acid receptor; GAD, glutamic acid decarboxylase; GlyR, glycine receptor; GABA ${ }_{A / B} R, \gamma-$ aminobutyric acid (A or B) receptor; CLIPPERS, chronic lymphocytic inflammation with pontine perivascular enhancement responsive to steroids 


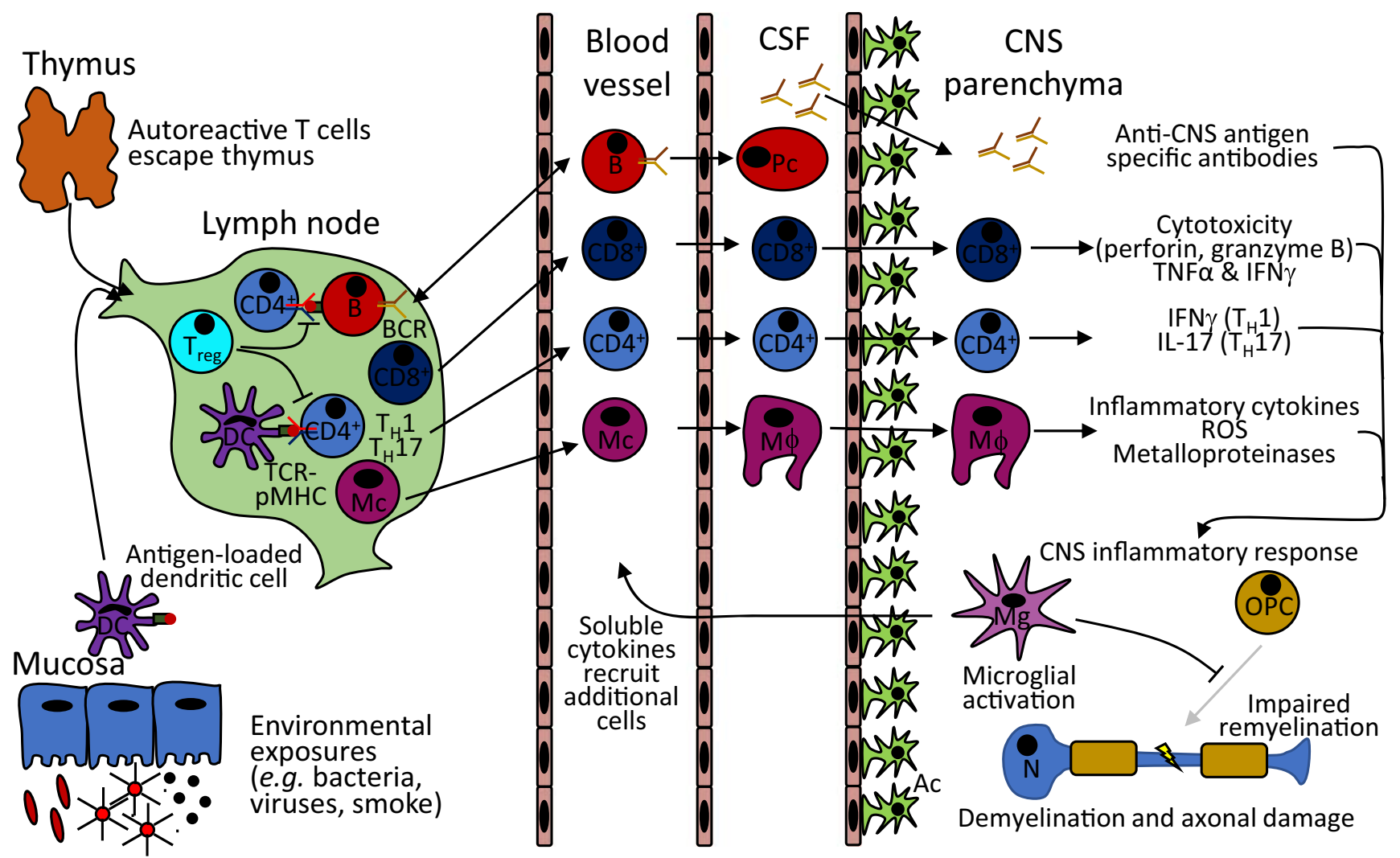

Fig. 1 Key cellular processes leading to CNS inflammation. This is a simplified schematic of adaptive and innate immune system processes culminating in CNS inflammation. For simplicity, this outline omits important roles of many cell types, such as NKT, MAIT and $\gamma \delta$ T cells, for which there is currently less evidence for a role of thymic selection in

relation to CNS autoimmune diseases. DC, dendritic cell; Mc, monocyte; $\mathrm{M} \phi$, macrophage; Pc, plasma cell; $\mathrm{Mg}$, microglia; OPC, oligodendrocyte precursor cell; N, neuron; Ac, astrocyte; TCR-pMHC, T cell receptorpeptide-major histocompatibility complex

discussed in depth here, but all are associated with CNS autoimmune disease and require intact thymopoiesis for their development [18-20].

Positive selection of conventional $\mathrm{T}$ cells occurs in the cortex and is mediated exclusively by cortical TECs (cTECs). Thymocytes are selected by stromal survival signals if they express a TCR with high affinity for its cognate peptide-MHC (pMHC) complex expressed on cTEC surfaces. Thymocytes that do not fulfil these criteria of MHC restriction (around 98\%) are prohibited from further maturation into $\mathrm{T}$ cells by withdrawal of selective stromal survival signals and die by neglect.

Negative selection of thymocytes occurs in both the cortex and medulla $[21,22]$. It is mediated by cTECs or mTECs together with other intrathymic APCs. In negative selection, antigen presentation induces apoptosis of thymocytes expressing TCRs with high affinity for autoantigens [23]. At the same time, thymocytes expressing TCRs with intermediate to high affinity for autoantigens, undergo a process of clonal diversion: engagement of autoantigens by their self-reactive TCR in presence of a favourable cytokine milieu (TGF $\beta$, IL-2) induces FoxP3 expression and differentiation into thymic $\mathrm{T}_{\text {reg }}\left(\mathrm{t} \mathrm{T}_{\text {reg }}\right)$, which limit peripheral $\mathrm{T}$ cell autoreactivity [24-27].

The balance between survival, clonal diversion and clonal deletion is principally determined by the affinity of TCRpMHC interactions.

\section{Molecular mechanisms of negative selection}

Establishment of thymic central tolerance by negative selection is dependent on the ability of thymocytes to respond differentially to the specific kinetics of TCR-pMHC binding. For example, TCR-pMHC complex binding triggers $\mathrm{Ca}^{2+}$ influx and extracellular-signal regulated kinase (ERK) activation: prolonged, low-level $\mathrm{Ca}^{2+}$ influx and ERK signalling maintains thymocyte survival, whereas rapid and robust ERK activation triggers clonal deletion [28]. Moreover, close to thymic selection thresholds (Fig. 2b), small quantitative increases in TCR ligand affinity and binding time trigger a qualitative shift in the phosphorylation status and subcellular compartmentalisation of Ras/MAPK signalling intermediates, whose recruitment to thymocyte membrane signals induction of negative selection [29].

Thymic negative selection requires that TECs present peptides derived from virtually all genes expressed within the body, a process known as promiscuous gene expression 


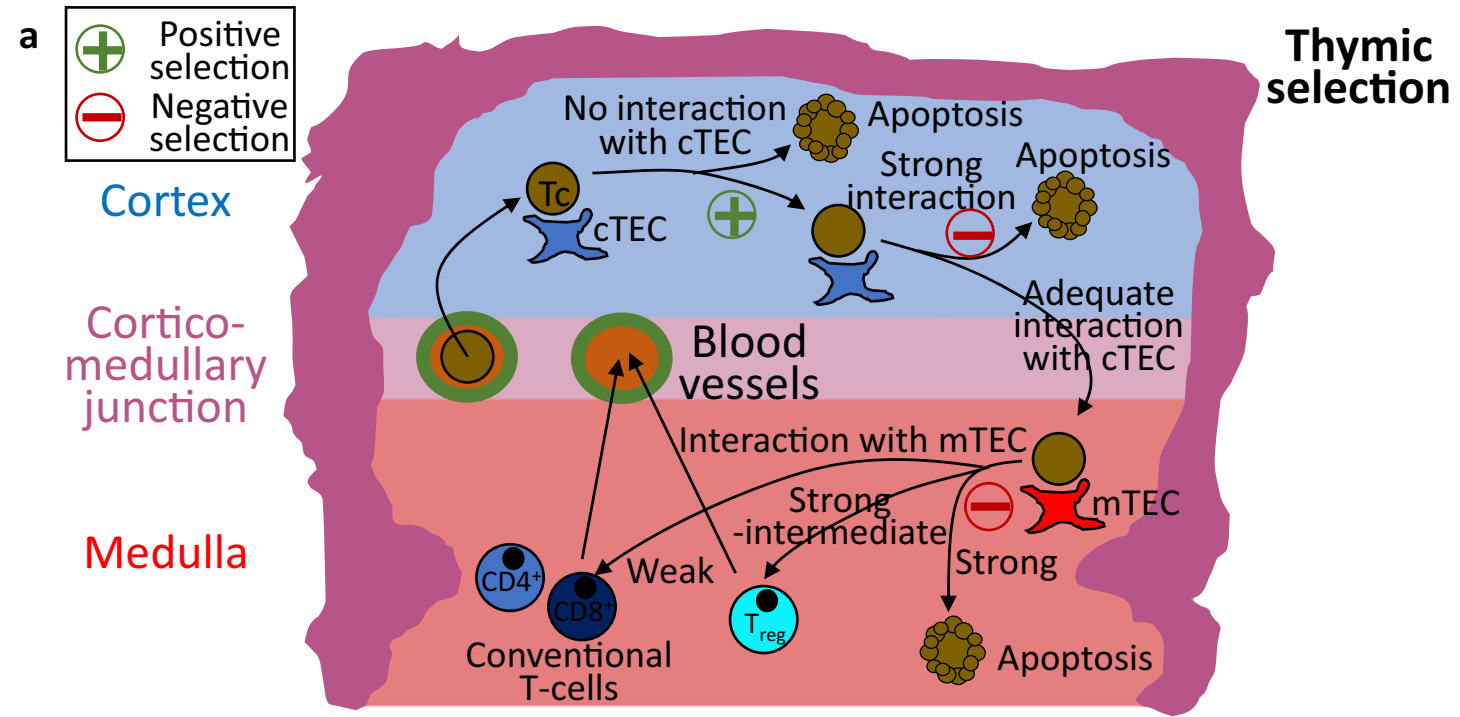

b

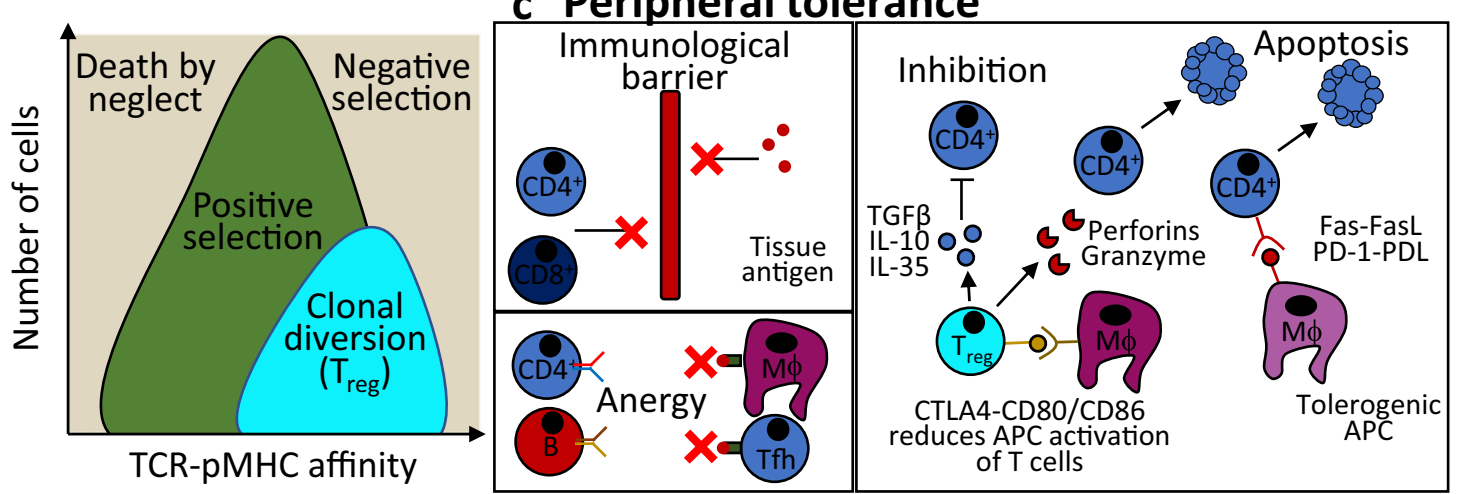

Fig. 2 Thymic and peripheral tolerance mechanisms. a An overview of thymocyte (Tc) and thymic epithelial cell (TEC) interactions within the thymus. b The thresholds of affinity model of thymic selection of thymocytes. c An overview of peripheral tolerogenic mechanisms

(PGE). mTECs use molecular pathways coordinated by the proteins AIRE ( 4000 genes) and FEZF2 $(\sim 400$ genes) to drive the expression of tissue-restricted antigens (TRA) and ensure that positively selected thymocytes are screened against a wide complement of self-peptides [30-32]. Genes regulated by AIRE-mediated PGE are associated with high levels of chromatin marks that characterise transcriptional repression.

The molecular orchestration of PGE in TEC is essential for the negative selection of thymocytes. However, TECs alone are insufficient to induce complete negative selection [33].

\section{TEC-independent negative selection}

Thymic APCs other than TECs, mainly intrathymic B cells and dendritic cells (DCs), also play an active role in TRA presentation. Firstly, intrathymic B cells directly participate in PGE. Circulating naïve B cells that immigrate into the thymus interact with cognate autoreactive $\mathrm{CD} 4^{+}$thymocytes via CD40: this leads to MHC-II and CD80 upregulation and "licences" B cells for AIRE expression, allowing TRA presentation and central tolerance induction [34]. Thymic B cells also contribute to clonal diversion into tTreg, and mTEC function and TRA presentation by lymphotoxin secretion $[35,36]$. DCs participate in negative thymocyte selection by three main mechanisms: thymic DCs present autoantigens found in thymic parenchyma or the medullary perivascular system [37]; circulating active DCs are recruited to the medulla to present autoantigens from peripheral tissues [38, 39]; thymic DCs present TEC-derived autoantigen through exosomal transfer [40]. DCs are known to present some encephalitogenic T cell epitopes to thymocytes, which may have implications for CNS autoimmunity [41, 42].

\section{Failure of negative selection}

A failure of negative selection is a requirement for peripheral $\mathrm{T}$ cell autoreactivity in both CNS autoimmunity and other organ-specific autoimmune diseases. Even under physiological conditions, TRA presentation to thymocytes is imperfect 
and permits potentially autoreactive $\mathrm{T}$ cells to escape to the periphery $[43,44]$.

In most circumstances, peripheral tolerance is able to compensate for incomplete thymic negative selection. This occurs through three main processes: intrinsic or acquired immune privilege [45], a key determinant of the relative contribution of thymic dysfunction to CNS autoimmunity; induction of T cell anergy [46]; and suppression of $\mathrm{T}$ cell responses by $\mathrm{T}_{\text {reg }}$ (Fig. 2c) $[11,47]$.

However, peripheral tolerogenic mechanisms cannot completely compensate for defective negative thymic selection, as illustrated by autoimmune polyendocrine syndrome type 1.

\section{Autoimmune polyendocrine syndrome type 1 (APS-1)}

Congenital loss-of-function AIRE mutations lead to the severe dysimmune manifestations observed in autoimmune polyendocrine syndrome type 1 (APS-1): hypoparathyroidism, adrenal insufficiency and chronic mucocutaneous candidiasis [48-50]. Many of these clinical manifestations are attributable to defective negative selection of thymocytes by mTEC. However, AIRE is also detectable in other cell types both within the thymus (AIRE-expressing B cells) and elsewhere (AIRE-expressing dendritic cells) [34, 51]. Evidence for the role of these non-mTEC AIRE-expressing cells in tolerance is controversial, particularly since recent data on the expression profile of human extrathymic AIRE-expressing dendritic cells suggest that AIRE does not drive TRA expression $[52,53]$.

Despite the aberrant $\mathrm{T}$ cell selection observed in APS-1, it is rare for autoimmune manifestations to affect the CNS beyond the pituitary gland $[54,55]$.

\section{CNS antigen presentation in the thymus}

The presence of peripheral, CNS-reactive T cells is difficult to reconcile with the lack of neuronal autoimmunity in APS-1. One possibility is that particular aspects of how CNS-specific TRAs are presented to thymocytes by mTEC and other thymic stromal cells may explain the relative lack of CNS manifestations in APS-1. TRAs in general have characteristic patterns of chromatin modifications, depleted for active chromatin (e.g. H3K4me3) and enriched for repressive chromatin (e.g. H3K27me3). CNS TRAs showed very similar chromatin modifications to other TRAs (Fig. 3a). Overall, CNS TRAs showed the highest expression within the population of mature mTEC (Fig. 3b). There was no evidence that the proportional expression or co-expression patterns of CNS TRAs were significantly different from TRAs of other tissues, suggesting that excessive redundancy in the expression of CNS antigens within the thymus is unlikely to account for the low frequency of CNS manifestations in APS-1 [13, 56-58] (Fig.
$3 \mathrm{c})$. It is possible that a mismatch between transcript expression and peptide abundance may explain part of this discrepancy; future studies are likely to examine this directly.

One characteristic that distinguishes CNS-specific TRAs from those found in other organs, is an enrichment for micro-exons: the expression of exonic sequences $\leq 30$ basepairs in length $[60,61]$. Relatively little is understood regarding the expression of micro-exon-containing genes within mTEC, but recent research suggests that micro-exons are poorly represented within the thymus with or without the expression of AIRE [62]. CNS antigens are also known to undergo post-translational modification [63]. In a similar fashion to micro-exons, the representation of posttranslationally modified TRA in thymus is incomplete [64]. The implications of these unique antigenic characteristics for CNS autoimmunity are currently unclear but would constitute potential routes by which developing thymocytes reactive against CNS TRAs could escape negative selection.

Overall, there are no characteristics of the thymic expression pattern of CNS-specific antigens that would explain why the CNS compartment is rarely affected in APS-1 patients.

\section{CNS-autoreactive T cells}

$\mathrm{T}$ cells contribute to the immunopathogenic mechanisms of CNS autoimmune diseases both via cellular immunity, involving direct induction of CNS inflammation along with innate immune cells, and humoral immunity, stimulating autoantibody production in $\mathrm{B}$ cells [65]. Evidence that $\mathrm{T}$ cells can result in CNS immune-mediated damage is provided by either CNS-reactive T cells in patient CNS tissue and/or cerebrospinal fluid (CSF) samples or association between HLA haplotypes and susceptibility to CNS autoimmune disease.

Neuropathological studies show autoreactive $\mathrm{T}$ cell infiltration is a feature of both paraneoplastic forms of autoimmune encephalitis, in which cytotoxic T cells and "onconeural" Abs are directed against intracellular CNS autoantigens, and autoimmune encephalitides characterised by autoantibodies against CNS surface self-antigens, e.g. NMDA receptors, leucine-rich glioma-inactivated protein 1 (LGI1) [66-69]. Similarly, in stiff person syndrome spectrum disorders (SPSDs), IFN $\gamma$ producing $\mathrm{CD}^{+} \mathrm{T}$ cells specific for an isoform of autoantigen glutamic acid decarboxylase (GAD65) can be isolated from patient blood and CSF samples and, in $~ 90 \%$ of patients, stimulate production of anti-GAD65 IgG autoantibodies by intrathecal B cells [70, 71]. In Rasmussen encephalitis, there is demonstrable infiltration of CNS parenchyma by IFN $\gamma$ producing $\mathrm{CD}^{+}, \mathrm{CD}^{+}$and $\gamma \delta-\mathrm{T}$ cells, although as of yet without an identifiable autoantigenic target [72, 73].

Beyond a direct role of $\mathrm{T}$ cells in autoimmune-mediated CNS toxicity, T cell help in the form of cytokines (e.g. IL-2) and co-stimulatory molecules (e.g. CD40 ligand) has been 


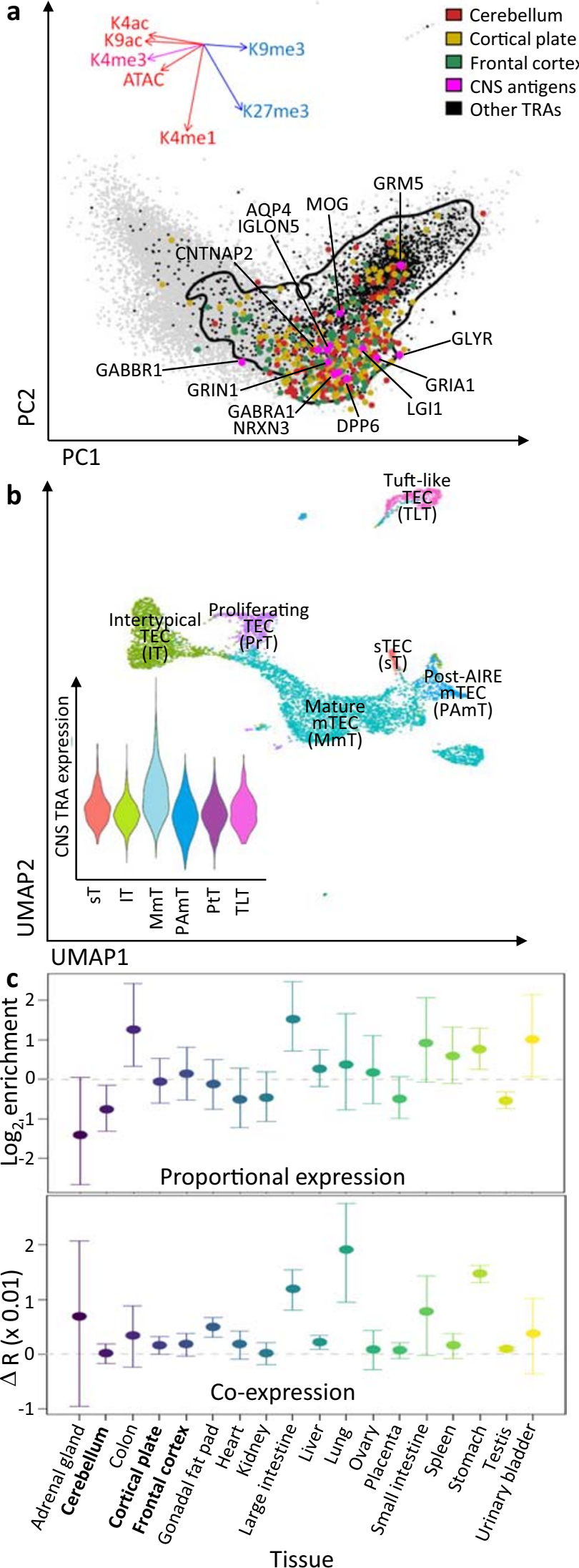

Fig. 3 Molecular characteristics of CNS antigen expression in the thymus. a A principal component plot of chromatin modifications in mature mTEC, highlighting CNS TRAs from cerebellum, cortical plate and frontal cortex. The positions of gene orthologues for known antigenic targets in CNS autoimmunity are labelled. The inset shows the contribution of each chromatin modification to the first and second principal components. The contour shows the $95 \%$ confidence interval for the kernel density of non-CNS TRAs. b A Uniform Manifold Approximation and Projection plot of single-cell RNA-seq TEC data (gated to exclude cTEC). The inset shows the overall module expression levels for CNS TRAs in each TEC subpopulation. TEC annotation was performed by transferring labels from an annotated dataset of TEC using Seurat $[58,59]$. c Plots of $\log _{2}$ enrichment for proportional expression and differential co-expression of TRAs within mature and post-AIRE mTECs relative to permuting TRA organ specificity labels 1000 times. Error bars show empirical 95\% confidence intervals. TRA organ specificity was defined as in [56]. Data was derived from $[56,57]$

identified as an important stimulant of B cell autoantibody production in patients with neuromyelitis optica spectrum disorders (NMOSD) and NMDA-receptor antibody encephalitis $[74,75]$.

In anti-PIT-1 antibody syndrome, a thymoma-associated form of autoimmune hypophysitis characterised by acquired GH, TSH and prolactin deficiency, both direct $\mathrm{T}$ cellmediated neurotoxicity and $\mathrm{T}$ cell humoral responses have been identified. There was $\mathrm{CD} 8^{+} \mathrm{T}$ cell infiltration of pituitary and other endocrine organs [76]. The correlation between levels of circulating anti-PIT 1 antibody and aberrant PIT-1 expression in thymomas supports the role of dysfunctional thymic selection in anti-PIT-1 antibody syndrome [77].

Association of HLA haplotypes with increased risk of CNS autoimmune disease also implicates $\mathrm{T}$ cell effects as key drivers of CNS inflammation. There is a $>90 \%$ association of the HLA-DRB1*07:01 allele with susceptibility to LGI1 antibody encephalitis, as well as a $\sim 50 \%$ association of the $H L A-D R B 1 * 11: 01$ allele with susceptibility to contactinassociated protein-like 2 (CASPR2)-mediated CNS autoimmune diseases [78]. This association with MHC class II HLA alleles demonstrates that autoantigen presentation to $T$ cells is a key process in the pathogenesis of LGI1 and CASPR2 antibody encephalitis.

Overall, these findings strongly indicate thymic escape of autoreactive $\mathrm{T}$ cells as an important pathophysiological mechanism in autoantibody-mediated CNS autoimmune diseases. However, the rarity of CNS manifestations in APS-1 argues that a failure of thymic selection alone is unlikely to be sufficient for CNS autoimmunity.

\section{Evidence for thymic tolerance in CNS inflammation}

The most commonly used model of CNS autoimmunity is experimental autoimmune encephalomyelitis (EAE): 
induction of cerebral and spinal inflammation by myelin autoantigens, such as myelin oligodendrocyte glycoprotein (MOG), proteolipid protein (PLP) and myelin basic protein (MBP). This system has been widely used to model the key features of human MS, albeit with several key clinical and pathophysiological differences between human CNS autoimmunity and EAE $[79,80]$.

\section{AIRE-dependent tolerance in CNS autoimmune disease}

Induction of EAE in AIRE-deficient mice can provide insight into the potential role of thymic tolerance in CNS autoimmunity. The susceptibility of Aire $e^{-/-}$mice to EAE is agedependent and correlates with the gradual reduction of an initially elevated number of $\mathrm{T}_{\text {reg }}$ cells in the brain parenchyma $[81,82]$. AIRE deficiency results in altered development and thymic recirculation of $T_{\text {reg }}$ as well as the inappropriate diversion of $\mathrm{T}_{\text {reg }}$ into an effector $\mathrm{T}$ cell phenotype [83-85]. However, further studies in MHC humanised, Aire ${ }^{-/-}$mice showed that, even with peripheral $\mathrm{T}_{\text {reg }}$ depletion, spontaneous CNS inflammation did not develop [86].

Overall, this supports clinical insights from APS-1 patients suggesting that impairment of thymic selection alone is insufficient for the development of CNS autoimmunity.

\section{$T_{\text {reg }}$ cells in CNS autoimmune disease}

Thymic $T_{\text {reg }}\left(t T_{\text {reg }}\right.$ - those $T_{\text {reg }}$ generated in the thymus) and peripheral $\mathrm{T}_{\text {reg }}\left(\mathrm{pT}_{\text {reg }}\right.$ - peripheral conversion of effector $\mathrm{T}$ cells into $T_{\text {reg }}$ ) cells have distinct roles in control of CNS inflammation [12]. Several studies show that $T_{\text {reg }}$ cellmediated immunomodulation has a pivotal role in protection from EAE and MS by suppression of peripheral myelin-reactive, potentially encephalitogenic T cells [87]. Acute depletion or functional inhibition of circulating $\mathrm{T}_{\text {reg }}$ cells in animal models exacerbates EAE course, and clinical studies suggest that $\mathrm{T}_{\text {reg }}$ cells in MS patients display defects in effector $\mathrm{T}$ cell suppression [88-90]. Presentation of neuronal antigenic material by DCs to autoreactive $\mathrm{T}$ cells in a non-inflammatory context leads to their differentiation into $\mathrm{Hopx}^{+} \mathrm{pT}_{\text {reg }}$ cells, which in turn provide long-lasting tolerance that protects from subsequent EAE induction [91]. MS patients exhibit defects in peripheral B cell tolerance in spite of normal central B cell selection, implicating dysfunction in $\mathrm{T}_{\text {reg }}$ cell-mediated modulation of peripheral B cell differentiation checkpoints [92]. Recent results from murine models have also identified a role of $\mathrm{T}_{\text {reg }}$ cells in promoting oligodendrocyte progenitor cell proliferation and remyelination [93].

$\mathrm{tT}_{\text {reg }}$ cells appear to be primarily involved in recovery from CNS autoimmunity. Spontaneous resolution of EAE in mice has been shown to involve accelerated $\mathrm{tT}_{\text {reg }}$ cell proliferation, differentiation and thymic output and is effectively prevented by thymectomy [94].

Systemic loss of $\mathrm{T}_{\text {reg }}$ cell function due to mutations in the $\mathrm{T}_{\text {reg }}$ master regulator, FOXP3, leads to immune dysregulation, polyendocrinopathy, enteropathy, and X-linked (IPEX) syndrome, characterised by severe multi-organ autoimmunity $[95,96]$. However, as with defective thymic selection in APS-1, CNS involvement in patients with IPEX syndrome is rare, with only one report of posterior reversible encephalopathy syndrome (PRES) [97].

Overall, this suggests that importance of $\mathrm{T}_{\text {reg }}$ cells in CNS autoimmunity reflects a combination of regenerative and immunomodulatory functions but that the loss of $\mathrm{T}_{\text {reg }}$ peripheral tolerogenic functions is insufficient to induce spontaneous CNS autoimmunity.

\section{Insight from genetic studies}

Several lines of genetic evidence highlight the necessity of normal thymus function to maintain homeostasis between effector and tolerogenic mechanisms of adaptive immunity in peripheral tissues, including the CNS. Mutations in genes required for thymus development and/or thymocyte selection have been associated with CNS autoimmunity or vice versa.

Development, differentiation and function of TECs require transcriptional master regulator Foxn1. MAP3K14 and IRF8, genes whose mouse orthologues are regulatory targets of Foxn1, have been implicated in MS by genome-wide association studies (GWAS) [98-100]. Conditional Foxn1 ablation in mice, which accelerates thymic involution, reduces Aire expression and disrupts negative selection, also induces autoimmune infiltration of pro-inflammatory cells in the CNS [101]. TEC-specific knockout of Map3k14 in mice leads to drastic decrease in thymic development and IL-17 secretion of dendritic epidermal $\gamma \delta \mathrm{T}$ cells, as a result of downstream loss of expression of Rorc and Il23r, genes required for IL-17 synthesis in $\gamma \delta \mathrm{T}$ cells [102]. As clinical studies have reported increased frequency of IL-17-producing $\gamma \delta \mathrm{T}$ cells in the CSF of MS patients, abnormal $\gamma \delta \mathrm{T}$ cell development may be important to the pathogenesis of CNS autoimmune disease [18]. Finally, Irf 8 is part of a transcriptional program that facilitates Aire expression in TECs; thus, Irf8 dysfunction may alter representation of AIRE-regulated CNS autoantigens in the thymus [103, 104].

Genetic evidence also points to associations between dysfunction in mechanisms of thymic selection and CNS autoimmunity. CLEC16A, variants of which are associated with susceptibility to MS, is involved in the control of TEC autophagy, a process that regulates MHC-associated thymic presentation of lysosomal, nuclear and mitochondrial peptide antigens $[105,106]$. Silencing of Clecl6a protects against autoimmunity by inducing $\mathrm{CD}^{+} \mathrm{T}$ cell hyporeactivity [106], and CLEC16A expression is upregulated in peripheral APCs of 
MS patients [107]. EAE severity in mice is exacerbated by dysfunction in PRSS16, which encodes a serine protease controlling peptide presentation to developing thymocytes $[108$, 109].

GWAS over the last decade have identified over 200 gene loci that independently contribute to MS pathogenesis [110]. Like many putative autoimmune diseases, major genetic variants associated with MS occur in the MHC class II subgroup of the HLA complex: HLA-DRB1*15:01-containing haplotypes carry the strongest association with MS risk [111]. Yet, the extent to which these variants affect thymic tolerance is difficult to determine, as specific haplotypes will both exert intrathymic effects on thymocyte selection and influence peripheral mechanisms of antigen presentation [112]. Autoimmunity-associated MHC polymorphisms are typically thought to alter TCR-pMHC complex binding dynamics and may cause extensive TCR-pMHC microcluster formation leading to escape of autoreactive $T$ cells $[113,114]$.

In general, characterisation of genetic pathways associated with thymic function is less comprehensive than pathways associated with peripheral innate or adaptive immune cells. Variants in other genes associated with susceptibility to MS or other CNS autoimmune diseases might hence affect central thymic tolerance processes in addition to their presently understood roles in peripheral immunity [110]. Emerging sequencing datasets from thymic stromal cells derived from murine or human samples will help annotate biological pathways important for thymic function $[115,116]$.

\section{Evidence from animal models}

\section{Responses to myelin autoantigens in mouse models of CNS autoimmunity}

The pathological effects of manipulating thymic expression of CNS antigens in murine EAE provide insight into the roles of thymic selection in CNS inflammation. Immunisation with PLP in $P l p 1^{\triangle T E C}$ mice, which lack thymic expression of resistance-associated PLP isoforms, leads to a more severe EAE course than in $P l p 1^{W T}$ mice [41]. This is consistent with previous studies showing that TEC expression of an encephalitogenic PLP splice isoform induces T cell tolerance for all PLP epitopes in EAE-resistant but not EAE-susceptible inbred mouse strains [117].

Similar protective effects of $M b p$ and Aqp thymic expression are seen in EAE models induced by MBP and AQP4 respectively, with peripheral expansion of CNS-reactive $\mathrm{T}$ cells not seen in wild-type mice $[118,119]$. Bypassing thymic tolerance via neonatal adoptive transfer into EAE-resistant rats of resting MBP-reactive T cells induces susceptibility to later EAE induction by MBP, despite MBP expression in TECs [120]. Similarly, transfer of $T_{H} 17$-polarised AQP4-specific cells into wild-type mice induces clinical and histologic signs of CNS autoimmune disease consistent with NMOSD [119].

Collectively, evidence suggests that experimental models of defective thymic selection can overwhelm peripheral tolerance mechanisms so that CNS-reactive T cells generate CNS autoimmunity. However, since these animal models do not develop spontaneous CNS inflammation in the absence of exogenous antigenic priming, it is unlikely that these models could completely recapitulate the complex pathophysiology of MS.

\section{Thymic dysfunction and the rarity of CNS inflammation}

This evidence of apparently dominant influences of central tolerance in some EAE models further highlights the paradox in the lack of spontaneous CNS autoimmunity in human (APS-1) and animal (Aire ${ }^{-/}$mice) models in which thymic selection is entirely absent. Two hypotheses have been advanced to explain this apparent contradiction.

The traditional view that the blood-brain barrier (BBB) entirely prevents infiltration of CNS-reactive T cells, making the CNS a perfectly immunoprivileged site, has been abandoned in light of current evidence [121]. In vivo tracing and imaging findings show that, under physiological conditions, $\mathrm{T}$ cells of heterogenous TCR specificities, including CNSreactive $T$ cells, frequently cross the BBB of meningeal and CNS parenchymal vessels to scan leptomeningeal and perivascular spaces for APC-presented antigen, suggesting that continuous trans-BBB immune cell trafficking is important to homeostatic immune surveillance of CNS parenchyma [122-124]. Recent findings have shown that the CNS harbours a complex network of $\mathrm{T}$ cells, which includes resting myelin-reactive $\mathrm{T}$ cells, involved in recovery from brain injury, CNS ageing and neurodegeneration, and higher cognitive function [125-128]. Disruption of homeostatic T cell surveillance is central to CNS inflammation [129]. Moreover, induction of BBB breakdown in the context of stroke rapidly induces clonal expansion of CNS-reactive $\mathrm{T}$ cells in brain parenchyma, indicating that partial immune privilege is important for the normal protection from CNS autoimmunity [130].

As well as this efferent arm (i.e. immune-cell CNS entry), the afferent arm of the neuroimmune axis influences roles of central and peripheral tolerance in CNS autoimmunity. The lymphatic system of the CNS, which includes glymphatic clearance of interstitial CNS solutes by CSF, drains soluble antigens and immune cells from CSF and CNS parenchyma into the cervical lymph nodes (CLNs) [131, 132]. The CNS lymphatic system constitutes a key site where CNS antigen presentation may trigger activation of CNS-reactive T cells. In rodents, antigens injected in CSF or brain parenchyma gradually accumulate in deep CLNs [133]. Both pharmacological ablation of meningeal lymphatics and dCLN resection 
attenuate EAE development, most likely by reducing licensing, reactivation and acquisition of encephalitogenic profile of CNS-reactive T cells in secondary lymphoid tissues [134, 135].

An additional explanation for the rarity of CNS inflammation in the context of thymic dysfunction is that antibodies against pro-inflammatory cytokines may preferentially block peripheral pathogenic processes leading to CNS autoimmunity. APS-1 patients, which lack T cell-dependent B cell tolerance, harbour high-affinity, strongly disease-ameliorating autoantibodies against type I interferons, which may account for the relative absence of CNS involvement in APS-1 [136].

Overall, it is likely that the combination of relative immune privilege and a constitutive anti-inflammatory state makes the CNS, under normal conditions, sufficiently resistant to induction of autoimmunity in spite of thymic escape of potentially encephalitogenic $T$ cell clones. This suggests that additional exogenous triggers are required to break peripheral tolerance in human CNS autoimmunity.

\section{Environmental triggers of CNS autoimmunity}

Animal models of CNS autoimmunity require exogenous priming with CNS antigens to break central and peripheral tolerance. Molecular mimicry between pathogen-derived antigens and autoantigens, leading to priming and later crossactivation of autoreactive $\mathrm{T}$ (and B) cells, may be a critical environmental factor required, in addition to thymic dysfunction, to trigger CNS autoimmunity under physiological conditions [137].

The strongest association between MS susceptibility and an environmental pathogen is with Epstein-Barr virus (EBV) [138, 139]. Crystallographic studies have revealed strong structural homology between TCR epitopes of HLA$D R B 1 * 15: 01$-restricted MBP and HLA-DRB5*01:01-restricted EBV peptides, suggesting that molecular mimicry may be a key determinant of the MHC class II link in MS [140]. Moreover, $\mathrm{EBV}$-specific $\mathrm{T}_{\mathrm{H}} 1$ cells from infected MS patients can cross-react against MBP peptides [141].

Molecular mimicry between AQP4 and Clostridium perfringens has been implicated as an environmental factor in NMOSD. NMO patients can harbour AQP4-specific $\mathrm{T}_{\mathrm{H}} 17$-polarised cells cross-reactive against $C$. perfringens antigens, and $C$. perfringens is overrepresented in their gut microbiome [142, 143].

Distinct from molecular mimicry, infections with a variety of pathogens can alter the phenotype and reactivity of cells migrating into the CNS $[144,145]$. This is an epitopeindependent mechanism by which environmental exposure could overwhelm peripheral tolerance in the presence of potentially autoreactive $\mathrm{T}$ cell clones that escaped thymic selection.

\section{Evidence from human autoimmune disease}

Due to clear differences in the pathophysiology of EAE and MS, findings from EAE in murine models cannot be directly extrapolated to human CNS autoimmune disease [79]. Importantly, the contribution of ongoing thymopoiesis to adaptive immunity differs between rodents and humans. In mice, robust thymic function allows lifelong thymocyte selection and naïve $\mathrm{T}$ cell output, whereas in humans, thymic involution starts in the second year of life [146]. Therefore, in contrast to mice, in adult humans adaptive immune function is mainly maintained by peripheral homeostatic proliferation of naïve and memory cells in an established $\mathrm{T}$ cell compartment. The early involution of human thymic tissue and its relative inaccessibility to clinical investigation have been major obstacles to studies of links between loss of thymic tolerance and CNS autoimmunity. Nonetheless, several lines of indirect evidence from patient studies point to potentially important roles of dysfunctions in thymic tolerance in human CNS autoimmune disease.

\section{Recent thymic emigrant cells and TREC measurements}

Quantification of T cell receptor excision circles (TRECs) is an indirect assay of thymic activity that circumvents tissue accessibility problems. TRECs are circular non-replicating DNA fragments, produced as a result of $\mathrm{V}(\mathrm{D}) \mathrm{J}$ recombination of TCR chain loci during thymocyte development, which can be detected in peripheral blood T cells [147-149]. The number of TRECs per million peripheral $\mathrm{T}$ cells correlates to the proportion of de novo $\mathrm{T}$ cells that have recently emigrated from the thymus and have not yet undergone substantial peripheral homeostatic proliferation.

Several studies have compared numbers of TRECs in peripheral $\mathrm{T}$ cells of MS patients versus healthy controls to determine the influence of thymopoiesis on the peripheral $\mathrm{T}$ cell clonal expansion found in MS [150-161]. Meta-analysis of these findings reveals a remarkably consistent reduction of TREC numbers in different subsets of peripheral lymphocytes in MS, which can be interpreted as a sign of accelerated or premature thymic senescence (Fig. 4). However, it is important to note that low TREC numbers do not unequivocally reflect reduction in thymic output of naïve $T$ cells, as increases in peripheral $\mathrm{T}$ cell proliferation will also dilute the proportion of recent thymic emigrants (RTEs) in the T cell compartment [162]. As not all TREC studies in MS patients sort T cell based on phenotypic markers, these do not provide conclusive evidence that MS-related decreases of TREC levels are due to reduced thymic output instead of homeostatic or antigeninduced $\mathrm{T}$ cell proliferation.

CD31 has been used as a selective marker to distinguish $\mathrm{CD} 1^{+}{ }^{-\mathrm{TREC}^{\text {hi }}} \mathrm{RTE} \mathrm{CD}^{+}{ }^{+} \mathrm{T}$ cells from $\mathrm{CD} 31^{-} \mathrm{TREC}^{\mathrm{lo}}$ 


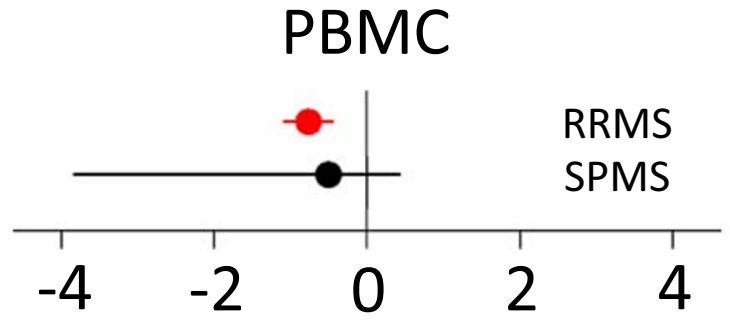

\section{$\mathrm{CD} 4^{+}$}

T-cells

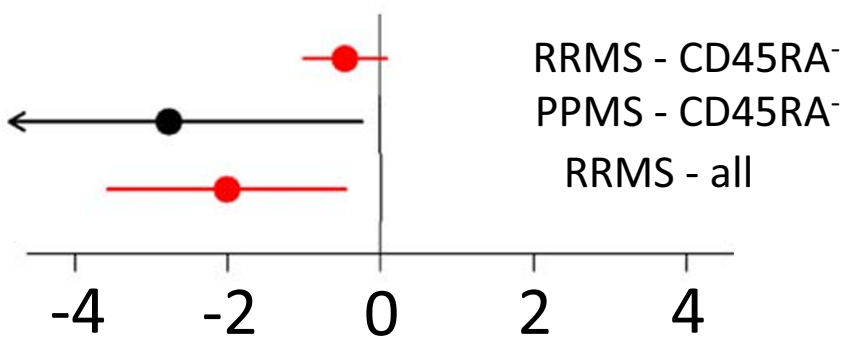

$\mathrm{CD} 8^{+}$

T-cells

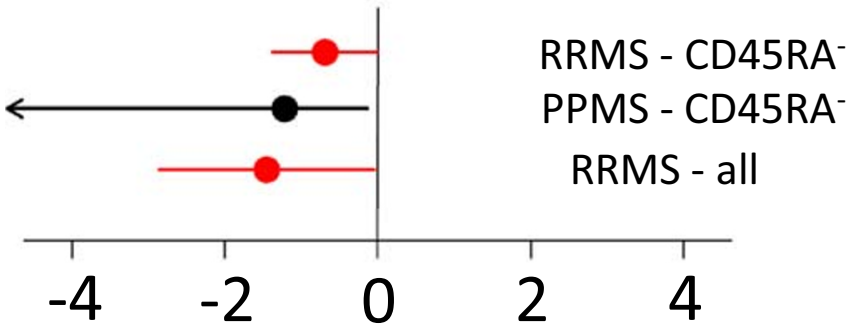

$T_{\text {reg }}$

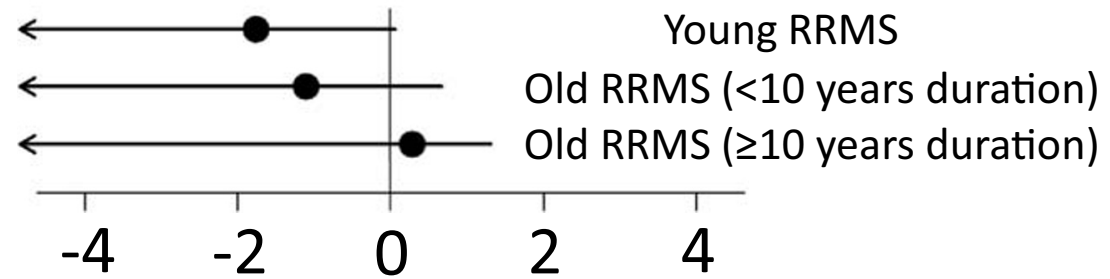

$\log _{2}$ ratio

(MS / healthy controls)

$\mathrm{CD}^{+} \mathrm{T}$ cells that have undergone homeostatic proliferation. The frequency of $\mathrm{CD} 31^{+}$RTE cells in blood are reduced in
MS patients relative to healthy controls [157-161, 163].

Furthermore, paediatric MS patients exhibit significantly 
Fig. 4 Measuring T cell receptor excision circles in MS. A schematic of selected elements of thymopoiesis. Log2 ratios of T cell receptor excision circle abundances between patients with MS and healthy controls are shown in forest plots. Red points indicate meta-analysed values inferred from a random effects model weighted by inverse variance. Standard errors were estimated from data presented in each study. RRMS, relapsing remitting MS; PPMS, primary progressive MS; SPMS, secondary progressive MS; $\mathrm{T}_{\text {reg, }}$, regulatory $\mathrm{T}$ cells; $\mathrm{PBMC}$, peripheral blood mononuclear cells. The scale bar indicates the magnitude of the $\log 2$ ratio

reduced levels of circulating CD31 ${ }^{+}$RTE effector T cells and $\mathrm{T}_{\text {reg }}$ cells relative to healthy controls as well as adult-like naïve/memory T cell ratios [164]. In addition, MS-associated genetic variants of IL7RA, which promotes early thymocyte survival, were associated with an increased frequency of RTEs [165]. These lines of evidence implicate premature intrinsic failure of thymopoiesis as a key factor in early onset of CNS autoimmunity.

\section{Clonal expansion of CNS-reactive T cells and TCR chain pairings}

As discussed above, CNS-reactive T cells are a central factor in the pathophysiology of human CNS autoimmune disease. Clonally expanded populations of peripheral CNS-reactive T cells, characterised by increased proliferation and proinflammatory cytokine release (IFN $\gamma$, IL-17, GM-CSF) in response to CNS antigens relative to healthy controls, have been observed in patients with MS, NMOSD and neuropsychiatric systemic lupus erythematosus (SLE) $[44,142,166]$.

Clonally expanded CNS-reactive $\mathrm{T}$ cell populations can be related to thymic selection defects by population-level highthroughput sequencing of TCR locus rearrangements, which allows to detect overrepresentations of TCR chain pairings in the peripheral $\mathrm{T}$ cell compartment. $\mathrm{T}$ cells from MS patients have more shared clonal TCR $\beta$ chain sequences between CNS, CSF and peripheral $\mathrm{T}$ cell pools than healthy controls $[167,168]$. Longitudinal TCR sequencing has shown that clonally expanded $\mathrm{T}$ cell populations could be detected in brain lesions, CSF and blood samples of a single patient with MS over an 18-year course, strongly suggesting that thymic escape of CNS-reactive $\mathrm{T}$ cells contributes to the peripheral pool of encephalitogenic $\mathrm{T}$ cells with subsequent maintenance by homeostatic proliferation [169].

\section{Roles of MS risk factors in thymopoiesis}

Indications of a link between the thymus and CNS autoimmune diseases have also come from analysis of MS risk factors. Some factors known to be associated with MS susceptibility, such as EBV infection, vitamin D levels, female sex and certain inflammatory or metabolic influences, have also been linked to alterations in thymopoiesis.

\section{EBV infection}

EBV infection is strongly associated with susceptibility to MS $[138,139]$. There is also evidence to suggest that EBV infection may strengthen links between thymic escape of autoreactive T cells and CNS pathology. Specifically, EBV infection of $\mathrm{B}$ cells in vitro increases secretion of chemokine CCL17 [170]. In turn, CCL17 in the thymus has been shown to influence differentiation and cytokine profiles of $\mathrm{t}_{\text {reg }}$ cells [171]. Moreover, interaction between CCL17 and its receptor CCR4 promotes pathogenesis of both EAE and MS by stimulating trans-BBB transmigration of $\mathrm{T}_{\mathrm{H}} 17$ cells $[172,173]$. However, the extent to which EBV infects cells within the thymus is controversial [174-177]. Collectively, data on the role of CCL17 provides tentative evidence that direct EBV infection of the thymus could alter thymic output and thus CNS inflammation.

\section{Vitamin D deficiency}

Low serum levels of 25-(OH)-vitamin $\mathrm{D}$, particularly in utero, in early life or during adolescence, are associated with increased risk of MS [178-183]. Exposure to low seasonal low levels of vitamin D either in utero or early in life has been proposed to underlie the month-of-birth effect on MS susceptibility $[184,185]$. Maternal vitamin D deficiency is indeed associated with reduced foetal thymic volume [186]. Low vitamin D levels later in life are not associated with reduced thymic output but are correlated with the proportion of $\mathrm{tT}_{\text {reg }}$ in the periphery $[187,188]$. Furthermore, thymic output, as measured by TREC levels, is correlated with month-of-birth [189], supporting a potential link between thymic output, vitamin D and MS susceptibility.

\section{Sex-related risk factors}

As observed in many other autoimmune diseases, MS risk is clearly associated with female sex [190]. It is likely that this female sex bias in MS susceptibility may involve sexdependent endocrine effects on thymic tolerance. Studies in rodents show that exposure to high oestrogen levels induces premature thymic atrophy associated with depletion of thymus-homing progenitors and reduced DN thymocyte proliferation, apoptosis of DP thymocytes and downregulation of AIRE expression with subsequent impairment of PGE in mTECs [191-195]. In contrast, androgen exposure upregulates thymic AIRE expression, leading to increased TRA presentation by TECs and thereby reduced EAE susceptibility via a male sex-dependent and AIRE-mediated process [196]. Sex hormone-related effects on thymic selection are 
therefore highly likely to contribute to the strong association between female sex and MS susceptibility.

\section{Inflammatory and metabolic risk factors}

Inflammatory and metabolic alterations associated with cigarette smoking and high body mass index (BMI) during childhood and adolescence, both of which constitute risk factors for MS [197, 198], have also been tentatively linked to disruption in thymic function. Maternal smoking has been linked to reduced neonatal thymic size, and prenatal nicotine exposure in mice results in persistent thymic hypoplasia with a reduction in $\mathrm{CD}^{+}$SP thymocytes $[199,200]$. Imaging studies also show that smoking and high BMI in adults are associated with premature fatty involution of the thymus [201, 202].

Overall, evidence that risk factors of CNS autoimmune disease are associated with thymic dysfunction is considerable but mainly indirect. Further research should thus focus on the effects of genetic risk loci, lifestyle factors and environmental exposures on alterations in thymic function [203].

\section{Evidence from alterations in thymic function}

As well as evidence that CNS autoimmune disease can be associated with thymic dysfunction, several studies have shown that direct disruption of thymic tolerance due to thymoma or thymectomy can be associated with alterations in CNS autoimmunity.

Thymic tumours can be associated with development of paraneoplastic autoimmune encephalitides involving CNS infiltration of cytotoxic $\mathrm{T}$ cells and onconeural autoantibodies. Benign and malignant thymomas, characterised by major alterations in $\mathrm{T}$ cell tolerance related to cortical thymic hyperplasia, are most frequently associated with myasthenia gravis (MG) [204]. There is also an association between thymoma and CNS autoimmunity (most commonly limbic encephalitis), a group of syndromes collectively referred to as thymoma-associated paraneoplastic encephalitis (TAPE) [205-209]. There have also been case reports of thymoma associated with SPSDs [210-212].

Thymectomy has been demonstrated to constitute an effective treatment for MG even in cases not associated with thymoma, consistent with the centrality of thymic dysfunction in MG [213]. Importantly, clinical improvement after thymectomy has also been reported in some cases of TAPE, showing that continuous thymic output of CNS antigen-specific T cells may play a significant role in CNS autoimmunity [205-209]. MG is also associated with susceptibility to NMOSD, particularly following thymectomy [214]. As most patients harbour anti-AQP4 antibodies years before thymectomy and disease onset, this risk appears to be independent of CNS-reactive antibody production and may instead reflect direct precipitation of CNS autoimmunity by the abrupt loss of thymopoiesis, possibly due to loss of thymic $\mathrm{tT}_{\text {reg }}$ cell output.

Despite major translational insights from preclinical findings, clinical interest in the potential for thymectomy as treatment for MS has been historically lacking after an early trial identified no benefit for thymectomy in patients with relapsing-remitting disease and showed worsening of clinical status in patients with chronic progressive disease [215]. Yet, the small number of patients and invasiveness of thymectomy limit interpretation of these results. More recently, there have been reports of significant clinical improvement after thymectomy in patients with concurrence of MG and MS, although the nature of this improvement is not clear [216]. Due to the lack of large-scale trials of thymectomy in MS patients, evidence of therapeutic effectiveness (or lack thereof) remains observational.

Since clinical improvement after MG or TAPE has been seen after thymectomy in adults, it is likely that modulation of thymoiesis into adulthood offers a potential useful therapeutic avenue.

\section{Evidence from effects of therapeutic strategies}

Just as alterations in thymic function can lead to pathophysiological features of CNS autoimmunity, successful therapeutic amelioration of CNS autoimmune disease can be associated with measurable changes in thymic $\mathrm{T}$ cell tolerance.

Comparative studies on treated versus untreated MS patients have sought to determine effects of different treatment strategies on numbers of TRECs and/or CD31 ${ }^{+}$RTE cells in peripheral blood mononuclear cells (PBMC) and in the $\mathrm{CD} 4^{+}$ or $\mathrm{CD} 8^{+} \mathrm{T}$ cell compartments specifically (Fig. 5) $[154,156$, 159-161, 217, 218]. The results of these have shown few consistent findings, although $\mathrm{T}$ cell subtype-specific effects would not be detected in these analyses.

Studies in MS patients subject to autologous haematopoietic stem cell transplantation (HSCT) show that an initial reduction in TREC levels is followed by recovery of the peripheral $\mathrm{T}$ cell pool over a 2-year course. This reconstituted $\mathrm{T}$ cell compartment is characterised by increased frequency of TREC ${ }^{\text {hi }} \mathrm{CD} 31^{+}$naïve RTE T cells and a broader TCR repertoire [217]. Myelin-reactive T cells that eventually re-emerge in the recovered $\mathrm{T}$ cell pool show significantly diminished $\mathrm{T}_{\mathrm{H}} 17$ responses, and this is associated with abrogation of focal inflammatory disease activity and MS relapses [218, 219]. Therefore, modulation of thymopoiesis leading to the appearance of RTE T cells can occur in adulthood and lead to clinically important changes in pathophysiological features of CNS autoimmunity.

Large and sustained increases in TREC levels are also observed during monoclonal antibody treatment with 
Fig. 5 Measuring $\mathrm{T}$ cell receptor excision circles in MS treatments. A forest plot of individual studies. IFN $\beta$, interferon-beta; HSCT, haematopoietic stem cell transplant; PBMC, peripheral blood mononuclear cells

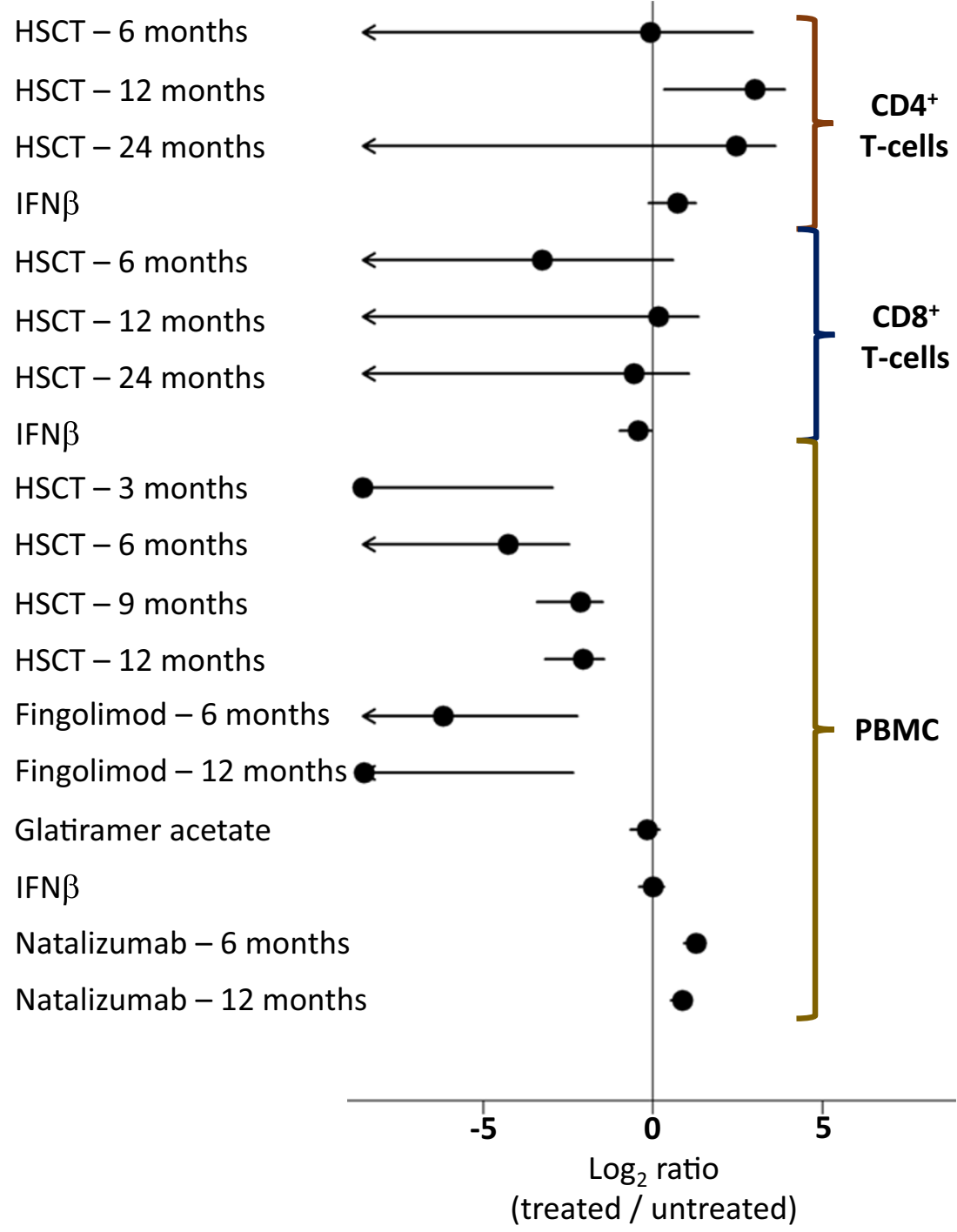

natalizumab, pointing to a therapeutic association with altered thymopoiesis [160]. In contrast, IFN $\beta$ and glatiramer acetate therapy have little effect on TREC levels [154, 156, 159] and major decreases in thymic $\mathrm{T}$ cell output are observed during immunomodulatory fingolimod therapy [161].

Evidence from treatment effects thus also points to potential therapeutic benefit of modulating thymopoiesis in CNS autoimmune diseases. More detailed functional phenotyping of RTE T cells associated with altered CNS inflammation is necessary in order to understand how changes in thymopoiesis are linked to reduction in the mechanisms of CNS autoimmunity.

\section{Therapeutic implications and future directions}

The modulation of thymopoiesis has unique potential as a source of novel therapies for CNS autoimmune diseases
[13]. While thymectomy constitutes the most direct approach, its routine application is unlikely since gross thymic abnormalities (e.g. thymoma, thymic hyperplasia) are far less frequent in CNS autoimmune diseases than in conditions for which thymectomy is an established treatment, such as $\mathrm{MG}$ [204, 213].

\section{Modulation of intrinsic and environmental factors for thymopoiesis}

A less invasive approach to reduce the risk of CNS autoimmunity and improve the effects of disease-modifying therapies could be to artificially manipulate intrinsic and environmental factors for thymic selection, in order to increase the elimination of autoreactive, potentially encephalitogenic $\mathrm{T}$ cells and promote generation of CNS-specific $\mathrm{tT}_{\text {reg }}$ cells.

If intrinsic defects in thymic selection play an important role in CNS autoimmunity, complete renewal of the developing thymocyte pool may yield therapeutic benefit. Clinical 
studies have indeed shown that, in relapsing-remitting MS patients, nonmyeloablative chemotherapy with antithymocyte globulin followed by autologous HSCT is associated with post-transplant improvement in disability scores, neurological function and CNS lesion volume, as well as prolonged time to disease progression compared to immunomodulatory therapy alone [220-222]. While these findings support modulation of thymopoiesis as a viable treatment for CNS autoimmunity, their interpretation is limited by evidence that immune system reconstitution by anti-thymocyte globulin does not just reset thymocyte selection but depletes the peripheral $\mathrm{T}$ cell pool as well. The role of $\mathrm{tT}_{\text {reg }}$ output in postHSCT improvement is also unclear, although HSCT is broadly associated with at least a transient increase in $T_{\text {reg }}$ numbers [223]. While CNS-specific $T_{\text {reg }}$ cells reduce neuroinflammation in animal models, development of protocols for efficient generation of human CNS-specific $\mathrm{T}_{\text {reg }}$ cells and trials in MS patients to determine the influence of these cells on CNS inflammatory profiles are required in order to effectively assess the therapeutic viability of $\mathrm{T}_{\text {reg }}$ cell-based approaches for human CNS autoimmune disease.

With increased understanding of how thymic tolerance changes in health and disease, it may also be possible to develop preventative strategies that target environmental factors that modulate thymopoiesis in early childhood to reduce risk of CNS autoimmunity in later life. Nutritional factors may play a role: both zinc and vitamin D supplementation has been shown to modulate thymopoiesis in mice [224-226]. However, evidence that vitamin D supplementation improves the course of MS is lacking [227]. Given the association of obesity and premature thymic involution, nutritional strategies aimed at control of BMI and adiposity may also have a protective effect for CNS autoimmunity [228].

In general, growing evidence that metabolism-, sex hormone- and ageing-related factors can have pervasive influences on thymic output and thus the composition of peripheral $\mathrm{T}$ cell pools suggests that multiple molecular pathways modulate thymopoiesis and could be preventatively targeted in patients, such as those with strong family history, at high risk for CNS autoimmunity [229, 230]. Large-scale studies, in which quantitative effects of manipulating specific environmental factors on thymopoiesis are measured, would need to be conducted before the therapeutic potential of these factors could be effectively assessed.

\section{Induced pluripotent stem cell-derived artificial thymic organoids}

An alternative and technologically more complex approach to modulate thymopoiesis is the in vitro differentiation from host-derived human induced pluripotent stem cells (iPSCs) of thymic epithelial progenitors (TEPs), which mature into functional TECs upon transplantation into the recipient.
More specifically, artificially bioengineered thymic epithelial tissue can be combined with biocompatible 3D scaffolds that mimic the organisation of thymic extracellular matrix to support ex vivo or even in situ generation of artificial thymic organoids (ATOs) [231-234].

Different studies have shown that ATOs can be generated from animal- and human-derived iPSCs or embryonic stem cells (as well as mature postnatal TECs) and can potentially support thymopoiesis in vitro [235-238]. Moreover, findings in athymic nude mice suggest ATO transplantation can effectively promote central $\mathrm{T}$ cell tolerance (i.e. reduce allograft rejection) [239].

Importantly, this approach can be combined with genetic manipulation of grafted autologous TEPs to ensure that their TEC progeny expresses desired or putative autoantigens and can thus limit thymic escape of potentially pathogenic $\mathrm{T}$ cells by fostering their clonal deletion or differentiation into antigen-specific tolerogenic $t T_{\text {reg }}$ cells. The potential efficacy of this strategy for CNS autoimmune diseases is supported by a proof-of-concept study in a preclinical model, in which transplantation of embryonic stem cell-derived TEPs engineered to express MOG rendered mice resistant to later EAE induction through deletion of MOG-autoreactive T cells and generation of MOG-specific $\mathrm{T}_{\text {reg }}$ cells [240].

Nonetheless, there are key limitations in current understanding of human thymic function that limit future therapeutic applicability of iPSC- and ATO-based approaches for CNS autoimmunity. Firstly, available in vitro models of human thymopoiesis and TCR repertoire selection are incomplete. Development of more sophisticated stem cell-derived thymic models, which can reliably recapitulate complexities of TEC function (especially transcriptional control of TRA gene expression) as well as the roles of intrathymic DCs and B cells, is required before clinical investigations can be pursued.

Furthermore, the less prominent role of thymopoiesis in adult maintenance of the peripheral $\mathrm{T}$ cell pool in humans than rodents is a potential obstacle to clinical translation of ATObased strategies [146]. However, the detection of CNSspecific RTE T cells following reconstitution of the peripheral T cell compartment by autologous or allogeneic HSCT in MS patients demonstrates that substantial potential for therapeutic targeting of thymopoiesis can be present in adulthood [218].

Finally, the correlation between intrathymic levels of CNS autoantigen transcripts, synthesis of CNS peptide antigens in TECs and actual presentation to thymocytes of potentially encephalitogenic TCR epitopes is itself only partly understood. Detailed characterisation of the TEC peptidome through recently developed high-throughput proteome screening assays is required to complement data from transcriptomic studies and thus resolve the proportion of CNS antigens that are effectively presented to developing thymocytes [241]. In turn, this would allow to evaluate more accurately the potential clinical benefits for CNS autoimmunity of approaches, 
such as ATO-based strategies, aimed at therapeutic modulation of the molecular mechanisms of thymic T cell tolerance.

\section{TCR clonality of RTE T cells as a measure of treatment effect and relapse risk}

An increased consideration of the role of the thymus in CNS autoimmunity in clinical settings could provide an important complement to existing therapies for CNS autoimmunity. In particular, advances in transcriptomic techniques could make the analysis of TCR clonality of recent thymic emigrant T cells a valuable tool to monitor the efficacy of available treatment approaches.

Population-level transcriptomic analysis of peripheral $\mathrm{T}$ cell pools allows to identify overrepresentation of specific $\operatorname{TCR} \beta$ chain locus rearrangements, which gives an indication of overall clonal diversity in peripheral $\mathrm{T}$ cells and allows to detect disease-relevant, clonally expanded $\mathrm{T}$ cell populations (e.g. in MS). Yet, these approaches cannot determine the specific TCR $\alpha$-and $\beta$-chain pairings in individual cells, which is required to understand TCR antigen specificity and clonality. By contrast, single-cell sequencing approaches make it possible to reconstruct full-length, $\alpha-\beta$ paired TCR sequences from the RNA sequencing data of individual T cells [242]. Such precise characterisation of the TCR repertoire allows the identification of clonal relationship between $\mathrm{T}$ cells and, most importantly, to predict their functional phenotype (e.g. effector/memory) and TCR ligand specificity.

Two main clinical applications can be envisaged for this approach. Firstly, comparing findings from TCR repertoire sequencing of RTE T cells in patients with CNS autoimmune diseases before and after treatment allows to detect whether CNS-reactive, pathogenic $\mathrm{T}$ cell clones persist or have been successfully eliminated. In turn, the detection of residual or reemerging pathogenic $\mathrm{T}$ cell clones gives an indication of treatment failure, allows to faithfully predict the occurrence of relapses and may direct the choice of alternative therapeutic approaches. Secondly, single-cell analysis of TCR clonality may allow the identification of novel antigens (e.g. due to epitope spreading) involved in the initiation or continuance of CNS autoimmune responses [243].

As for other strategies, a major knowledge gap limits the potential for testing the practicality of single-cell sequencingbased treatment approaches in preclinical disease models and patient-based studies. Specifically, future research should focus on providing a more detailed description of how thymic antigen presentation, thymopoiesis and the TCR repertoire of RTE T cell populations vary as a function of age (in particular with thymic senescence), as well as on examining the impact on CNS inflammation of the different functional phenotypes of CNS-specific RTE T cells that emerge after therapeutic haematopoietic stem cell transplantation for CNS autoimmune diseases.

\section{Conclusions}

Research into the roles of central tolerance in human CNS autoimmunity has considerably lagged behind research into peripheral tolerogenic mechanisms. Nonetheless, evidence from both preclinical models and studies in human patients over the last two decades has suggested a role for the thymus in susceptibility to and severity of CNS inflammation, and therefore in the risk, pathogenesis, progression and response to treatment of CNS autoimmune disease, in particular MS.

There are still major gaps in our understanding and ability to measure how thymopoiesis and central $\mathrm{T}$ cell tolerance change during health and disease, as well as in our ability to discriminate the influences of central tolerance induction and peripheral tolerogenic processes in pathophysiological features of CNS inflammation. Critically, a detailed and comprehensive functional phenotyping of all innate and adaptive immune cells isolated from the CNS is still lacking, although is beginning to emerge from recent studies [244]. Understanding of this would be fundamental to a clearer elucidation of the relationship between the CNS and the peripheral $\mathrm{T}$ cell compartment, which may resolve why the CNS is resistant to autoimmunity even in the presence of disrupted thymic selection (e.g. in APS-1). In turn, these knowledge gaps significantly limit the potential for translating the modulation of thymic selection into viable therapeutic strategies for CNS autoimmune disease. The promise of these therapeutic approaches should act to stimulate further research in this area.

In the next decade, studies providing an improved understanding of the roles of thymic tolerance in autoimmune diseases of the CNS may support the emergence of novel interventions with greater efficacy and a lower risk of adverse effects than currently available therapeutic options.

Funding AEH was supported by a Clinical Lectureship from NIHR and by a grant from the MRC (MR/S036407/1).

Data availability Not applicable

\section{Compliance with ethical standards}

Conflict of interest The authors declare that they have no conflict of interest.

Ethics approval Not applicable

Consent to participate Not applicable

Consent for publication The authors consent to publication of this manuscript.

Code availability Not applicable 
Open Access This article is licensed under a Creative Commons Attribution 4.0 International License, which permits use, sharing, adaptation, distribution and reproduction in any medium or format, as long as you give appropriate credit to the original author(s) and the source, provide a link to the Creative Commons licence, and indicate if changes were made. The images or other third party material in this article are included in the article's Creative Commons licence, unless indicated otherwise in a credit line to the material. If material is not included in the article's Creative Commons licence and your intended use is not permitted by statutory regulation or exceeds the permitted use, you will need to obtain permission directly from the copyright holder. To view a copy of this licence, visit http://creativecommons.org/licenses/by/4.0/.

\section{References}

1. Global, regional, and national burden of neurological disorders (2019) 1990-2016: a systematic analysis for the Global Burden of Disease Study 2016. Lancet Neurol 18(5):459-480

2. Global, regional, and national burden of multiple sclerosis 19902016 (2019) A systematic analysis for the Global Burden of Disease Study 2016. Lancet Neurol 18(3):269-285

3. Kobelt G, Thompson A, Berg J, Gannedahl M, Eriksson J (2017) New insights into the burden and costs of multiple sclerosis in Europe. Mult Scler 23(8):1123-1136

4. Dendrou CA, Fugger L, Friese MA (2015) Immunopathology of multiple sclerosis. Nat Rev Immunol 15(9):545-558

5. Takaba H, Takayanagi $H$ (2017) The mechanisms of T cell selection in the thymus. Trends Immunol 38(11):805-816

6. Mueller DL (2010) Mechanisms maintaining peripheral tolerance. Nat Immunol 11(1):21-27

7. Riedhammer C, Weissert R (2015) Antigen presentation, autoantigens, and immune regulation in multiple sclerosis and other autoimmune diseases. Front Immunol 6:322

8. Wardemann H, Yurasov S, Schaefer A, Young JW, Meffre E, Nussenzweig MC (2003) Predominant autoantibody production by early human B cell precursors. Science 301(5638):1374-1377

9. Tiller T, Tsuiji M, Yurasov S, Velinzon K, Nussenzweig MC, Wardemann H (2007) Autoreactivity in human IgG+ memory B cells. Immunity 26(2):205-213

10. Cambier JC, Gauld SB, Merrell KT, Vilen BJ (2007) B-cell anergy: from transgenic models to naturally occurring anergic $\mathrm{B}$ cells? Nat Rev Immunol 7(8):633-643

11. Vignali DA, Collison LW, Workman CJ (2008) How regulatory T cells work. Nat Rev Immunol 8(7):523-532

12. Jones A, Hawiger D (2017) Peripherally induced regulatory T cells: recruited protectors of the central nervous system against autoimmune neuroinflammation. Front Immunol 8:532

13. Handel AE, Irani SR, Hollander GA (2018) The role of thymic tolerance in CNS autoimmune disease. Nat Rev Neurol 14(12):723-734

14. Hollander G, Gill J, Zuklys S, Iwanami N, Liu C, Takahama Y (2006) Cellular and molecular events during early thymus development. Immunol Rev 209:28-46

15. Anderson G, Takahama Y (2012) Thymic epithelial cells: working class heroes for $\mathrm{T}$ cell development and repertoire selection. Trends Immunol 33(6):256-263

16. Anderson G, Jenkinson EJ (2001) Lymphostromal interactions in thymic development and function. Nat Rev Immunol 1(1):31-40

17. Pear WS, Radtke F (2003) Notch signaling in lymphopoiesis. Semin Immunol 15(2):69-79

18. Schirmer L, Rothhammer V, Hemmer B, Korn T (2013) Enriched CD161high CCR6+ $\gamma \delta \mathrm{T}$ cells in the cerebrospinal fluid of patients with multiple sclerosis. JAMA Neurol 70(3):345-351
19. Heming M, Schulte-Mecklenbeck A, Brix T, Wolbert J, Ruland T, Klotz L, Meuth SG, Gross CC, Wiendl H, Meyer zu Hörste G (2019) Immune cell profiling of the cerebrospinal fluid provides pathogenetic insights into inflammatory neuropathies. Front Immunol 10:515. https://doi.org/10.3389/fimmu.2019.00515

20. Mexhitaj I, Nyirenda MH, Li R, O'Mahony J, Rezk A, Rozenberg A, Moore CS, Johnson T, Sadovnick D, Collins DL, Arnold DL, Gran B, Yeh EA, Marrie RA, Banwell B, Bar-Or A (2019) Abnormal effector and regulatory $\mathrm{T}$ cell subsets in paediatriconset multiple sclerosis. Brain 142(3):617-632

21. Jensen KD, Chien YH (2009) Thymic maturation determines gammadelta $\mathrm{T}$ cell function, but not their antigen specificities. Curr Opin Immunol 21(2):140-145

22. McCaughtry TM, Baldwin TA, Wilken MS, Hogquist KA (2008) Clonal deletion of thymocytes can occur in the cortex with no involvement of the medulla. J Exp Med 205(11):2575-2584

23. Xing Y, Hogquist KA (2012) T-cell tolerance: central and peripheral. Cold Spring Harb Perspect Biol 4(6):a006957. https://doi. org/10.1101/cshperspect.a006957

24. Aschenbrenner K, D'Cruz LM, Vollmann EH, Hinterberger M, Emmerich J, Swee LK, Rolink A, Klein L (2007) Selection of Foxp3+ regulatory $\mathrm{T}$ cells specific for self-antigen expressed and presented by Aire+ medullary thymic epithelial cells. Nat Immunol 8(4):351-358

25. Bautista JL, Lio CW, Lathrop SK, Forbush K, Liang Y, Luo J, Rudensky AY, Hsieh CS (2009) Intraclonal competition limits the fate determination of regulatory $\mathrm{T}$ cells in the thymus. Nat Immunol 10(6):610-617

26. Leung MW, Shen S, Lafaille JJ (2009) TCR-dependent differentiation of thymic Foxp3+ cells is limited to small clonal sizes. J Exp Med 206(10):2121-2130

27. Liu Y, Zhang P, Li J, Kulkarni AB, Perruche S, Chen W (2008) A critical function for TGF-beta signaling in the development of natural CD4+CD25+Foxp3+ regulatory T cells. Nat Immunol 9(6):632-640

28. McNeil LK, Starr TK, Hogquist KA (2005) A requirement for sustained ERK signaling during thymocyte positive selection in vivo. Proc Natl Acad Sci U S A 102(38):13574-13579

29. Daniels MA, Teixeiro E, Gill J, Hausmann B, Roubaty D, Holmberg K, Werlen G, Hollander GA, Gascoigne NR, Palmer E (2006) Thymic selection threshold defined by compartmentalization of Ras/MAPK signalling. Nature 444(7120):724-729

30. Anderson MS, Venanzi ES, Klein L, Chen Z, Berzins SP, Turley SJ, von Boehmer H, Bronson R, Dierich A, Benoist C, Mathis D (2002) Projection of an immunological self shadow within the thymus by the aire protein. Science 298(5597):1395-1401

31. Takaba H, Morishita Y, Tomofuji Y, Danks L, Nitta T, Komatsu N, Kodama T, Takayanagi H (2015) Fezf2 orchestrates a thymic program of self-antigen expression for immune tolerance. Cell 163(4):975-987

32. Sansom SN, Shikama N, Zhanybekova S, Nusspaumer G, Macaulay IC, Deadman ME, Heger A, Ponting CP, Holländer GA (2014) Population and single cell genomics reveal the Airedependency, relief from polycomb silencing and distribution of self-antigen expression in thymic epithelia. Genome Res 24(12): 1918-1931

33. Lancaster JN, Thyagarajan HM, Srinivasan J, Li Y, Hu Z, Ehrlich LIR (2019) Live-cell imaging reveals the relative contributions of antigen-presenting cell subsets to thymic central tolerance. Nature Communications 10(1):2220

34. Yamano T, Nedjic J, Hinterberger M, Steinert M, Koser S, Pinto S, Gerdes N, Lutgens E, Ishimaru N, Busslinger M, Brors B, Kyewski B, Klein L (2015) Thymic B cells are licensed to present self antigens for central $\mathrm{T}$ cell tolerance induction. Immunity 42(6):1048-1061 
35. Walters SN, Webster KE, Daley S, Grey ST (2014) A role for intrathymic B cells in the generation of natural regulatory $\mathrm{T}$ cells. The Journal of Immunology 193(1):170-176

36. Akirav EM, Xu Y, Ruddle NH (2011) Resident B cells regulate thymic expression of myelin oligodendrocyte glycoprotein. J Neuroimmunol 235(1-2):33-39

37. Atibalentja DF, Byersdorfer CA, Unanue ER (2009) Thymusblood protein interactions are highly effective in negative selection and regulatory T cell induction. J Immunol 183(12):7909-7918

38. Bonasio R, Scimone ML, Schaerli P, Grabie N, Lichtman AH, von Andrian UH (2006) Clonal deletion of thymocytes by circulating dendritic cells homing to the thymus. Nat Immunol 7(10): 1092-1100

39. Hadeiba H, Lahl K, Edalati A, Oderup C, Habtezion A, Pachynski R, Nguyen L, Ghodsi A, Adler S, Butcher EC (2012) Plasmacytoid dendritic cells transport peripheral antigens to the thymus to promote central tolerance. Immunity 36(3):438-450

40. Koble C, Kyewski B (2009) The thymic medulla: a unique microenvironment for intercellular self-antigen transfer. J Exp Med 206(7):1505-1513

41. Wang L, Winnewisser J, Federle C, Jessberger G, Nave KA, Werner HB, Kyewski B, Klein L, Hinterberger M (2017) Epitope-specific tolerance modes differentially specify susceptibility to proteolipid protein-induced experimental autoimmune encephalomyelitis. Front Immunol 8:1511

42. Perchellet A, Brabb T, Goverman JM (2008) Crosspresentation by nonhematopoietic and direct presentation by hematopoietic cells induce central tolerance to myelin basic protein. Proc Natl Acad Sci U S A 105(37):14040-14045

43. Cebula A, Kuczma M, Szurek E, Pietrzak M, Savage N, Elhefnawy WR, Rempala G, Kraj P, Ignatowicz L (2019) Dormant pathogenic CD4(+) T cells are prevalent in the peripheral repertoire of healthy mice. Nat Commun 10(1):4882

44. Cao Y, Goods BA, Raddassi K, Nepom GT, Kwok WW, Love JC, Hafler DA (2015) Functional inflammatory profiles distinguish myelin-reactive $\mathrm{T}$ cells from patients with multiple sclerosis. Science Translational Medicine 7(287):287ra74

45. Mellor AL, Munn DH (2008) Creating immune privilege: active local suppression that benefits friends, but protects foes. Nat Rev Immunol 8(1):74-80

46. Kalekar LA, Schmiel SE, Nandiwada SL, Lam WY, Barsness LO, Zhang N, Stritesky GL, Malhotra D, Pauken KE, Linehan JL, O'Sullivan MG, Fife BT, Hogquist KA, Jenkins MK, Mueller DL (2016) CD4(+) T cell anergy prevents autoimmunity and generates regulatory T cell precursors. Nat Immunol 17(3):304-314

47. Legoux FP, Lim JB, Cauley AW, Dikiy S, Ertelt J, Mariani TJ, Sparwasser T, Way SS, Moon JJ (2015) CD4+ T cell tolerance to tissue-restricted self antigens is mediated by antigen-specific regulatory $\mathrm{T}$ cells rather than deletion. Immunity 43(5):896-908

48. Pignata C, Fiore M, Guzzetta V, Castaldo A, Sebastio G, Porta F, Guarino A (1996) Congenital alopecia and nail dystrophy associated with severe functional T-cell immunodeficiency in two sibs. Am J Med Genet 65(2):167-170

49. An autoimmune disease (1997) APECED, caused by mutations in a novel gene featuring two PHD-type zinc-finger domains. Nat Genet 17(4):399-403

50. Taniguchi RT, DeVoss JJ, Moon JJ, Sidney J, Sette A, Jenkins MK, Anderson MS (2012) Detection of an autoreactive T-cell population within the polyclonal repertoire that undergoes distinct autoimmune regulator (Aire)-mediated selection. Proceedings of the National Academy of Sciences 109(20):7847-7852

51. Gardner JM, Metzger TC, McMahon EJ, Au-Yeung BB, Krawisz AK, Lu W, Price JD, Johannes KP, Satpathy AT, Murphy KM, Tarbell KV, Weiss A, Anderson MS (2013) Extrathymic Aireexpressing cells are a distinct bone marrow-derived population that induce functional inactivation of $\mathrm{CD} 4+\mathrm{T}$ cells. Immunity 39(3):560-572

52. Mouri Y, Ueda Y, Yamano T, Matsumoto M, Tsuneyama K, Kinashi T, Matsumoto M (2017) Mode of tolerance induction and requirement for Aire are governed by the cell types that express self-antigen and those that present antigen. J. Immunol. 199(12):3959-3971

53. Fergusson JR, Morgan MD, Bruchard M, Huitema L, Heesters BA, van Unen V, van Hamburg JP, van der Wel NN, Picavet D, Koning F, Tas SW, Anderson MS, Marioni JC, Holländer GA, Spits H (2019) Maturing human CD127+ CCR7+ PDL1+ dendritic cells express AIRE in the absence of tissue restricted antigens. Front Immunol 9:2902. https://doi.org/10.3389/fimmu.2018. 02902

54. Guo C-J, Leung PSC, Zhang W, Ma X, Gershwin ME (2018) The immunobiology and clinical features of type 1 autoimmune polyglandular syndrome (APS-1). Autoimmun Rev 17(1):78-85

55. Mazza C, Buzi F, Ortolani F, Vitali A, Notarangelo LD, Weber G, Bacchetta R, Soresina A, Lougaris V, Greggio NA, Taddio A, Pasic S, de Vroede M, Pac M, Kilic SS, Ozden S, Rusconi R, Martino S, Capalbo D, Salerno M, Pignata C, Radetti G, Maggiore G, Plebani A, Notarangelo LD, Badolato R (2011) Clinical heterogeneity and diagnostic delay of autoimmune polyendocrinopathy-candidiasis-ectodermal dystrophy syndrome. Clin. Immunol. 139(1):6-11

56. Handel AE, Shikama-Dorn N, Zhanybekova S, Maio S, Graedel AN, Zuklys S, Ponting CP, Hollander GA (2018) Comprehensively profiling the chromatin architecture of tissue restricted antigen expression in thymic epithelial cells over development. Front Immunol 9:2120

57. Dhalla F, Baran-Gale J, Maio S, Chappell L, Hollander GA, Ponting CP (2020) Biologically indeterminate yet ordered promiscuous gene expression in single medullary thymic epithelial cells. EMBO J 39(1):e101828

58. Baran-Gale J, Morgan M, Maio S, Dhalla F, Calvo-Asensio I, Deadman M, Handel A, Maynard A, Chen S, Green F, Sit R, Neff N, Darmanis S, Tan W, May A, Marioni J, Ponting C, Holländer G (2020) Ageing compromises mouse thymus function and remodels epithelial cell differentiation. Elife 9:e56221

59. Stuart T, Butler A, Hoffman P, Hafemeister C, Papalexi E, Mauck WM 3rd, Hao Y, Stoeckius M, Smibert P, Satija R (2019) Comprehensive integration of single-cell data. Cell 177(7):18881902.e21

60. Quesnel-Vallieres M, Dargaei Z, Irimia M, GonatopoulosPournatzis T, Ip JY, Wu M, Sterne-Weiler T, Nakagawa S, Woodin MA, Blencowe BJ, Cordes SP (2016) Misregulation of an activity-dependent splicing network as a common mechanism underlying autism spectrum disorders. Mol Cell 64(6):1023-1034

61. Quesnel-Vallieres M, Irimia M, Cordes SP, Blencowe BJ (2015) Essential roles for the splicing regulator nSR100/SRRM4 during nervous system development. Genes Dev 29(7):746-759

62. Jansen K, Shikama-Dorn N, Attar M, Maio S, Lopopolo M, Buck D, Holländer G, Sansom S (2020) Rbfox contributes to a conservative program of self-antigen splicing in thymic epithelial cells, bioRxiv. https://doi.org/10.1101/2020.03.06.980870

63. Zhang C, Walker AK, Zand R, Moscarello MA, Yan JM, Andrews PC (2012) Myelin basic protein undergoes a broader range of modifications in mammals than in lower vertebrates. $\mathrm{J}$ Proteome Res 11(10):4791-4802

64. Raposo B, Merky P, Lundqvist C, Yamada H, Urbonaviciute V, Niaudet C, Viljanen J, Kihlberg J, Kyewski B, Ekwall O, Holmdahl R, Backlund J (2018) T cells specific for posttranslational modifications escape intrathymic tolerance induction. Nat Commun 9(1):353 
65. Simon AK, Hollander GA, McMichael A (2015) Evolution of the immune system in humans from infancy to old age. Proc Biol Sci 282(1821):20143085

66. Newman MP, Blum S, Wong RC, Scott JG, Prain K, Wilson RJ, Gillis D (2016) Autoimmune encephalitis. Intern Med J 46(2): $148-157$

67. Graus F, Saiz A, Lai M, Bruna J, López F, Sabater L, Blanco Y, Rey MJ, Ribalta T, Dalmau J (2008) Neuronal surface antigen antibodies in limbic encephalitis. Neurology 71(12):930-936

68. Bauer J, Becker AJ, Elyaman W, Peltola J, Rüegg S, Titulaer MJ, Varley JA, Beghi E (2017) Innate and adaptive immunity in human epilepsies. Epilepsia 58 Suppl 3(Suppl Suppl 3):57-68

69. Bien CG, Vincent A, Barnett MH, Becker AJ, Blümcke I, Graus F, Jellinger KA, Reuss DE, Ribalta T, Schlegel J, Sutton I, Lassmann H, Bauer J (2012) Immunopathology of autoantibody-associated encephalitides: clues for pathogenesis. Brain 135(Pt 5):16221638

70. Burton AR, Baquet Z, Eisenbarth GS, Tisch R, Smeyne R, Workman CJ, Vignali DA (2010) Central nervous system destruction mediated by glutamic acid decarboxylase-specific CD4+ T cells. J Immunol 184(9):4863-4870

71. Skorstad G, Hestvik AL, Vartdal F, Holmøy T (2009) Cerebrospinal fluid $\mathrm{T}$ cell responses against glutamic acid decarboxylase 65 in patients with stiff person syndrome. J Autoimmun 32(1):24-32

72. Schwab N, Bien CG, Waschbisch A, Becker A, Vince GH, Dornmair K, Wiendl H (2009) CD8+ T-cell clones dominate brain infiltrates in Rasmussen encephalitis and persist in the periphery. Brain 132(Pt 5):1236-1246

73. Al Nimer F, Jelcic I, Kempf C, Pieper T, Budka H, Sospedra M, Martin R (2018) Phenotypic and functional complexity of braininfiltrating $\mathrm{T}$ cells in Rasmussen encephalitis. Neurol Neuroimmunol Neuroinflamm 5(1):e419

74. Wilson R, Makuch M, Kienzler AK, Varley J, Taylor J, Woodhall M, Palace J, Leite MI, Waters P, Irani SR (2018) Conditiondependent generation of aquaporin-4 antibodies from circulating B cells in neuromyelitis optica. Brain 141(4):1063-1074

75. Makuch M, Wilson R, Al-Diwani A, Varley J, Kienzler AK, Taylor J, Berretta A, Fowler D, Lennox B, Leite MI, Waters P, Irani SR (2018) N-methyl-D-aspartate receptor antibody production from germinal center reactions: therapeutic implications. Ann Neurol 83(3):553-561

76. Bando H, Iguchi G, Fukuoka H, Yamamoto M, Hidaka-Takeno R, Okimura Y, Matsumoto R, Suda K, Nishizawa H, Takahashi M, Tojo K, Takahashi Y (2014) Involvement of PIT-1-reactive cytotoxic T lymphocytes in anti-PIT-1 antibody syndrome. J Clin Endocrinol Metab 99(9):E1744-E1749

77. Bando H, Iguchi G, Okimura Y, Odake Y, Yoshida K, Matsumoto R, Suda K, Nishizawa H, Fukuoka H, Mokubo A, Tojo K, Maniwa Y, Ogawa W, Takahashi Y (2017) A novel thymomaassociated autoimmune disease: Anti-PIT-1 antibody syndrome. Sci Rep 7:43060

78. Binks S, Varley J, Lee W, Makuch M, Elliott K, Gelfand JM, Jacob S, Leite MI, Maddison P, Chen M, Geschwind MD, Grant E, Sen A, Waters P, McCormack M, Cavalleri GL, Barnardo M, Knight JC, Irani SR (2018) Distinct HLA associations of LGI1 and CASPR2-antibody diseases. Brain 141(8):2263-2271

79. Gold R, Linington C, Lassmann H (2006) Understanding pathogenesis and therapy of multiple sclerosis via animal models: 70 years of merits and culprits in experimental autoimmune encephalomyelitis research. Brain 129(Pt 8):1953-1971

80. Handel AE, Lincoln MR, Ramagopalan SV (2011) Of mice and men: experimental autoimmune encephalitis and multiple sclerosis. Eur J Clin Invest 41(11):1254-1258
81. Aharoni R, Aricha R, Eilam R, From I, Mizrahi K, Arnon R, Souroujon MC, Fuchs S (2013) Age dependent course of EAE in Aire-/- mice. J Neuroimmunol 262(1-2):27-34

82. Anderson MS, Venanzi ES, Chen Z, Berzins SP, Benoist C, Mathis D (2005) The cellular mechanism of Aire control of T cell tolerance. Immunity 23(2):227-239

83. Malchow S, Leventhal DS, Lee V, Nishi S, Socci ND, Savage PA (2016) Aire enforces immune tolerance by directing autoreactive $\mathrm{T}$ cells into the regulatory $\mathrm{T}$ cell lineage. Immunity 44(5):11021113

84. Lei Y, Ripen AM, Ishimaru N, Ohigashi I, Nagasawa T, Jeker LT, Bösl MR, Holländer GA, Hayashi Y, de Waal Malefyt R, Nitta T, Takahama Y (2011) Aire-dependent production of XCL1 mediates medullary accumulation of thymic dendritic cells and contributes to regulatory $\mathrm{T}$ cell development. Journal of Experimental Medicine 208(2):383-394

85. Cowan JE, Baik S, McCarthy NI, Parnell SM, White AJ, Jenkinson WE, Anderson G (2018) Aire controls the recirculation of murine Foxp3(+) regulatory T-cells back to the thymus. Eur J Immunol 48(5):844-854

86. Nalawade SA, Ji N, Raphael I, Pratt A 3rd, Kraig E, Forsthuber TG (2018) Aire is not essential for regulating neuroinflammatory disease in mice transgenic for human autoimmune-diseases associated MHC class II genes HLA-DR2b and HLA-DR4. Cell Immunol 331:38-48

87. Duffy SS, Keating BA, Perera CJ, Moalem-Taylor G (2018) The role of regulatory $\mathrm{T}$ cells in nervous system pathologies. $\mathrm{J}$ Neurosci Res 96(6):951-968

88. Lafaille JJ, Nagashima K, Katsuki M, Tonegawa S (1994) High incidence of spontaneous autoimmune encephalomyelitis in immunodeficient anti-myelin basic protein $\mathrm{T}$ cell receptor transgenic mice. Cell 78(3):399-408

89. Kohm AP, McMahon JS, Podojil JR, Begolka WS, DeGutes M, Kasprowicz DJ, Ziegler SF, Miller SD (2006) Cutting Edge: AntiCD25 monoclonal antibody injection results in the functional inactivation, not depletion, of CD4+CD25+ T regulatory cells. J Immunol 176(6):3301-3305

90. Venken K, Hellings N, Thewissen M, Somers V, Hensen K, Rummens JL, Medaer R, Hupperts R, Stinissen P (2008) Compromised CD4+ CD25(high) regulatory T-cell function in patients with relapsing-remitting multiple sclerosis is correlated with a reduced frequency of FOXP3-positive cells and reduced FOXP3 expression at the single-cell level. Immunology 123(1): 79-89

91. Jones A, Opejin A, Henderson JG, Gross C, Jain R, Epstein JA, Flavell RA, Hawiger D (2015) Peripherally induced tolerance depends on peripheral regulatory $\mathrm{T}$ cells that require Hopx to inhibit intrinsic IL-2 expression. J Immunol 195(4):1489-1497

92. Kinnunen T, Chamberlain N, Morbach H, Cantaert T, Lynch M, Preston-Hurlburt P, Herold KC, Hafler DA, O'Connor KC, Meffre E (2013) Specific peripheral B cell tolerance defects in patients with multiple sclerosis. J Clin Invest 123(6):2737-2741

93. Dombrowski Y, O'Hagan T, Dittmer M, Penalva R, Mayoral SR, Bankhead P, Fleville S, Eleftheriadis G, Zhao C, Naughton M, Hassan R, Moffat J, Falconer J, Boyd A, Hamilton P, Allen IV, Kissenpfennig A, Moynagh PN, Evergren E, Perbal B, Williams AC, Ingram RJ, Chan JR, Franklin RJM, Fitzgerald DC (2017) Regulatory $\mathrm{T}$ cells promote myelin regeneration in the central nervous system. Nat Neurosci 20(5):674-680

94. Chen X, Fang L, Song S, Guo TB, Liu A, Zhang JZ (2009) Thymic regulation of autoimmune disease by accelerated differentiation of Foxp3+ regulatory T cells through IL-7 signaling pathway. J Immunol 183(10):6135-6144

95. Verbsky JW, Chatila TA (2013) Immune dysregulation, polyendocrinopathy, enteropathy, X-linked (IPEX) and IPEX- 
related disorders: an evolving web of heritable autoimmune diseases. Curr Opin Pediatr 25(6):708-714

96. Bacchetta R, Barzaghi F, Roncarolo MG (2018) From IPEX syndrome to FOXP3 mutation: a lesson on immune dysregulation. Ann N Y Acad Sci 1417(1):5-22

97. Bae KW, Kim BE, Choi JH, Lee JH, Park YS, Kim GH, Yoo HW, Seo JJ (2011) A novel mutation and unusual clinical features in a patient with immune dysregulation, polyendocrinopathy, enteropathy, X-linked (IPEX) syndrome. Eur J Pediatr 170(12):16111615

98. Žuklys S, Handel A, Zhanybekova S, Govani F, Keller M, Maio S, Mayer CE, Teh HY, Hafen K, Gallone G, Barthlott T, Ponting CP, Holländer GA (2016) Foxn1 regulates key target genes essential for $\mathrm{T}$ cell development in postnatal thymic epithelial cells. Nat Immunol 17(10):1206-1215

99. Chrabot BS, Kariuki SN, Zervou MI, Feng X, Arrington J, Jolly M, Boumpas DT, Reder AT, Goulielmos GN, Niewold TB (2013) Genetic variation near IRF8 is associated with serologic and cytokine profiles in systemic lupus erythematosus and multiple sclerosis. Genes Immun 14(8):471-478

100. Hussman JP, Beecham AH, Schmidt M, Martin ER, McCauley JL, Vance JM, Haines JL, Pericak-Vance MA (2016) GWAS analysis implicates NF-kB-mediated induction of inflammatory $\mathrm{T}$ cells in multiple sclerosis. Genes Immun 17(5):305-312

101. Xia J, Wang H, Guo J, Zhang Z, Coder B, Su DM (2012) Agerelated disruption of steady-state thymic medulla provokes autoimmune phenotype via perturbing negative selection. Aging Dis 3(3):248-259

102. Mair F, Joller S, Hoeppli R, Onder L, Hahn M, Ludewig B, Waisman A, Becher B (2015) The NFkB-inducing kinase is essential for the developmental programming of skin-resident and IL-17-producing $\gamma \delta$ T cells. Elife 4:e10087

103. Herzig Y, Nevo S, Bornstein C, Brezis MR, Ben-Hur S, Shkedy A, Eisenberg-Bord M, Levi B, Delacher M, Goldfarb Y, David E, Weinberger L, Viukov S, Ben-Dor S, Giraud M, Hanna JH, Breiling A, Lyko F, Amit I, Feuerer M, Abramson J (2017) Transcriptional programs that control expression of the autoimmune regulator gene Aire. Nat Immunol 18(2):161-172

104. Giraud M, Taubert R, Vandiedonck C, Ke X, Lévi-Strauss M, Pagani F, Baralle FE, Eymard B, Tranchant C, Gajdos P, Vincent A, Willcox N, Beeson D, Kyewski B, Garchon HJ (2007) An IRF8-binding promoter variant and AIRE control CHRNA1 promiscuous expression in thymus. Nature 448(7156):934-937

105. Berge T, Leikfoss IS, Harbo HF (2013) From identification to characterization of the multiple sclerosis susceptibility gene CLEC16A. Int J Mol Sci 14(3):4476-4497

106. Schuster C, Gerold KD, Schober K, Probst L, Boerner K, Kim MJ, Ruckdeschel A, Serwold T, Kissler S (2015) The autoimmunityassociated gene CLEC16A modulates thymic epithelial cell autophagy and alters T cell selection. Immunity 42(5):942-952

107. van Luijn MM, Kreft KL, Jongsma ML, Mes SW, Wierenga-Wolf AF, van Meurs M, Melief MJ, der Kant R, Janssen L, Janssen H, Tan R, Priatel JJ, Neefjes J, Laman JD, Hintzen RQ (2015) Multiple sclerosis-associated CLEC16A controls HLA class II expression via late endosome biogenesis. Brain 138(Pt 6):15311547

108. Gommeaux J, Grégoire C, Nguessan P, Richelme M, Malissen M, Guerder S, Malissen B, Carrier A (2009) Thymus-specific serine protease regulates positive selection of a subset of CD4+ thymocytes. Eur J Immunol 39(4):956-964

109. Serre L, Girard M, Ramadan A, Menut P, Rouquié N, Lucca LE, Mahiddine K, Leobon B, Mars LT, Guerder S (2017) Thymicspecific serine protease limits central tolerance and exacerbates experimental autoimmune encephalomyelitis. J Immunol 199(11):3748-3756
110. International Multiple Sclerosis Genetics Consortium (2019) Multiple sclerosis genomic map implicates peripheral immune cells and microglia in susceptibility. Science 365(6460):eaav7188

111. Ramagopalan SV, Ebers GC (2009) Multiple sclerosis: major histocompatibility complexity and antigen presentation. Genome Med 1(11): 105

112. Lincoln MR, Ramagopalan SV, Chao MJ, Herrera BM, Deluca GC, Orton SM, Dyment DA, Sadovnick AD, Ebers GC (2009) Epistasis among HLA-DRB1, HLA-DQA1, and HLA-DQB1 loci determines multiple sclerosis susceptibility. Proc Natl Acad Sci U S A 106(18):7542-7547

113. Yoshida K, Corper AL, Herro R, Jabri B, Wilson IA, Teyton L (2010) The diabetogenic mouse MHC class II molecule I-Ag7 is endowed with a switch that modulates TCR affinity. J Clin Invest 120(5):1578-1590

114. Schubert DA, Gordo S, Sabatino JJ Jr, Vardhana S, Gagnon E, Sethi DK, Seth NP, Choudhuri K, Reijonen H, Nepom GT, Evavold BD, Dustin ML, Wucherpfennig KW (2012) Selfreactive human $\mathrm{CD} 4 \mathrm{~T}$ cell clones form unusual immunological synapses. J Exp Med 209(2):335-352

115. Kadouri N, Nevo S, Goldfarb Y, Abramson J (2020) Thymic epithelial cell heterogeneity: TEC by TEC. Nat Rev Immunol 20(4):239-253

116. Park JE, Botting RA, Conde CD, Popescu DM, Lavaert M, Kunz DJ, Goh I, Stephenson E, Ragazzini R, Tuck E, Wilbrey-Clark A, Roberts K, Kedlian VR, Ferdinand JR, He X, Webb S, Maunder D, Vandamme N, Mahbubani KT, Polanski K, Mamanova L, Bolt L, Crossland D, de Rita F, Fuller A, Filby A, Reynolds G, Dixon D, Saeb-Parsy K, Lisgo S, Henderson D, Vento-Tormo R, Bayraktar OA, Barker RA, Meyer KB, Saeys Y, Bonfanti P, Behjati S, Clatworthy MR, Taghon T, Haniffa M, Teichmann SA (2020) A cell atlas of human thymic development defines T cell repertoire formation. Science 367(6480):eaay3224

117. Klein L, Klugmann M, Nave KA, Tuohy VK, Kyewski B (2000) Shaping of the autoreactive T-cell repertoire by a splice variant of self protein expressed in thymic epithelial cells. Nat Med 6(1):5661

118. Targoni OS, Lehmann PV (1998) Endogenous myelin basic protein inactivates the high avidity $\mathrm{T}$ cell repertoire. Journal of Experimental Medicine 187(12):2055-2063

119. Sagan SA, Winger RC, Cruz-Herranz A, Nelson PA, Hagberg S, Miller CN, Spencer CM, Ho PP, Bennett JL, Levy M, Levin MH, Verkman AS, Steinman L, Green AJ, Anderson MS, Sobel RA, Zamvil SS (2016) Tolerance checkpoint bypass permits emergence of pathogenic $\mathrm{T}$ cells to neuromyelitis optica autoantigen aquaporin-4. PNAS 113(51):14781-14786 201617859

120. Volovitz I, Mor F, Machlenkin A, Goldberger O, Marmor Y, Eisenbach L, Cohen IR (2009) T-cell seeding: neonatal transfer of anti-myelin basic protein T-cell lines renders Fischer rats susceptible later in life to the active induction of experimental autoimmune encephalitis. Immunology 128(1):92-102

121. Engelhardt B, Vajkoczy P, Weller RO (2017) The movers and shapers in immune privilege of the CNS. Nature Immunology 18(2):123-131

122. Greter M, Heppner FL, Lemos MP, Odermatt BM, Goebels N, Laufer T, Noelle RJ, Becher B (2005) Dendritic cells permit immune invasion of the CNS in an animal model of multiple sclerosis. Nat Med 11(3):328-334

123. Kyratsous NI, Bauer IJ, Zhang G, Pesic M, Bartholomäus I, Mues M, Fang P, Wörner M, Everts S, Ellwart JW, Watt JM, Potter BVL, Hohlfeld R, Wekerle H, Kawakami N (2017) Visualizing context-dependent calcium signaling in encephalitogenic $\mathrm{T}$ cells in vivo by two-photon microscopy. Proc Natl Acad Sci U S A 114(31):E6381-e6389 
124. Alves de Lima K, Rustenhoven J, Kipnis J (2020) Meningeal immunity and its function in maintenance of the central nervous system in health and disease. Annu Rev Immunol 38:597-620

125. Schwartz M, Raposo C (2014) Protective autoimmunity: a unifying model for the immune network involved in CNS repair. Neuroscientist 20(4):343-358

126. Walsh JT, Zheng J, Smirnov I, Lorenz U, Tung K, Kipnis J (2014) Regulatory $\mathrm{T}$ cells in central nervous system injury: a doubleedged sword. The Journal of Immunology 193(10):5013-5022

127. Mrdjen D, Pavlovic A, Hartmann FJ, Schreiner B, Utz SG, Leung BP, Lelios I, Heppner FL, Kipnis J, Merkler D, Greter M, Becher B (2018) High-dimensional single-cell mapping of central nervous system immune cells reveals distinct myeloid subsets in health, aging, and disease. Immunity 48(2):380-395.e6

128. Kipnis J, Gadani S, Derecki NC (2012) Pro-cognitive properties of T cells. Nat Rev Immunol 12(9):663-669

129. Bartholomäus I, Kawakami N, Odoardi F, Schläger C, Miljkovic D, Ellwart JW, Klinkert WE, Flügel-Koch C, Issekutz TB, Wekerle H, Flügel A (2009) Effector T cell interactions with meningeal vascular structures in nascent autoimmune CNS lesions. Nature 462(7269):94-98

130. Römer C, Engel O, Winek K, Hochmeister S, Zhang T, Royl G, Klehmet J, Dirnagl U, Meisel C, Meisel A (2015) Blocking strokeinduced immunodeficiency increases CNS antigen-specific autoreactivity but does not worsen functional outcome after experimental stroke. J Neurosci 35(20):7777-7794

131. Iliff JJ, Wang M, Liao Y, Plogg BA, Peng W, Gundersen GA, Benveniste H, Vates GE, Deane R, Goldman SA, Nagelhus EA, Nedergaard M (2012) A paravascular pathway facilitates CSF flow through the brain parenchyma and the clearance of interstitial solutes, including amyloid $\beta$. Sci Transl Med 4(147):147ra111

132. Louveau A, Smirnov I, Keyes TJ, Eccles JD, Rouhani SJ, Peske JD, Derecki NC, Castle D, Mandell JW, Lee KS, Harris TH, Kipnis J (2015) Structural and functional features of central nervous system lymphatic vessels. Nature 523(7560):337

133. Cserr HF, Harling-Berg CJ, Knopf PM (1992) Drainage of brain extracellular fluid into blood and deep cervical lymph and its immunological significance. Brain Pathol 2(4):269-276

134. van Zwam M, Huizinga R, Heijmans N, van Meurs M, WierengaWolf AF, Melief MJ, Hintzen RQ, Hart BAT, Amor S, Boven LA, Laman JD (2009) Surgical excision of CNS-draining lymph nodes reduces relapse severity in chronic-relapsing experimental autoimmune encephalomyelitis. J Pathol 217(4):543-551

135. Louveau A, Herz J, Alme MN, Salvador AF, Dong MQ, Viar KE, Herod SG, Knopp J, Setliff JC, Lupi AL, Da Mesquita S, Frost EL, Gaultier A, Harris TH, Cao R, Hu S, Lukens JR, Smirnov I, Overall CC, Oliver G, Kipnis J (2018) CNS lymphatic drainage and neuroinflammation are regulated by meningeal lymphatic vasculature. Nat Neurosci 21(10):1380-1391

136. Meyer S, Woodward M, Hertel C, Vlaicu P, Haque Y, Kärner J, Macagno A, Onuoha SC, Fishman D, Peterson H, Metsküla K, Uibo R, Jäntti K, Hokynar K, Wolff ASB, Krohn K, Ranki A, Peterson P, Kisand K, Hayday A (2016) AIRE-deficient patients harbor unique high-affinity disease-ameliorating autoantibodies. Cell 166(3):582-595

137. Rojas M, Restrepo-Jiménez P, Monsalve DM, Pacheco Y, AcostaAmpudia Y, Ramírez-Santana C, Leung PSC, Ansari AA, Gershwin ME, Anaya JM (2018) Molecular mimicry and autoimmunity. J Autoimmun 95:100-123

138. Handel AE, Williamson AJ, Disanto G, Handunnetthi L, Giovannoni G, Ramagopalan SV (2010) An updated meta-analysis of risk of multiple sclerosis following infectious mononucleosis. PLoS One 5(9):e12496. https://doi.org/10.1371/journal. pone.0012496

139. Munger KL, Levin LI, O'Reilly EJ, Falk KI, Ascherio A (2011) Anti-Epstein-Barr virus antibodies as serological markers of multiple sclerosis: a prospective study among United States military personnel. Mult. Scler. 17(10):1185-1193

140. Lang HL, Jacobsen H, Ikemizu S, Andersson C, Harlos K, Madsen L, Hjorth P, Sondergaard L, Svejgaard A, Wucherpfennig K, Stuart DI, Bell JI, Jones EY, Fugger L (2002) A functional and structural basis for TCR cross-reactivity in multiple sclerosis. Nat Immunol 3(10):940-943

141. Lünemann JD, Jelčić I, Roberts S, Lutterotti A, Tackenberg BR, Martin R, Münz C (2008) EBNA1-specific T cells from patients with multiple sclerosis cross react with myelin antigens and coproduce IFN- $\gamma$ and IL-2. Journal of Experimental Medicine 205(8):1763-1773

142. Varrin-Doyer M, Spencer CM, Schulze-Topphoff U, Nelson PA, Stroud RM, Cree BA, Zamvil SS (2012) Aquaporin 4-specific T cells in neuromyelitis optica exhibit a Th17 bias and recognize Clostridium ABC transporter. Ann Neurol 72(1):53-64

143. Cree BA, Spencer CM, Varrin-Doyer M, Baranzini SE, Zamvil SS (2016) Gut microbiome analysis in neuromyelitis optica reveals overabundance of Clostridium perfringens. Ann Neurol 80(3): 443-447

144. McManus RM, Higgins SC, Mills KH, Lynch MA (2014) Respiratory infection promotes $\mathrm{T}$ cell infiltration and amyloidbeta deposition in APP/PS1 mice. Neurobiol Aging 35(1):109121

145. Paroni M, Maltese V, De Simone M, Ranzani V, Larghi P, Fenoglio C, Pietroboni AM, De Riz MA, Crosti MC, Maglie S, Moro M, Caprioli F, Rossi R, Rossetti G, Galimberti D, Pagani M, Scarpini E, Abrignani S, Geginat J (2017) Recognition of viral and self-antigens by TH1 and TH1/TH17 central memory cells in patients with multiple sclerosis reveals distinct roles in immune surveillance and relapses. J Allergy Clin Immunol 140(3):797808

146. den Braber I, Mugwagwa T, Vrisekoop N, Westera L, Mögling R, de Boer AB, Willems N, Schrijver EH, Spierenburg G, Gaiser K, Mul E, Otto SA, Ruiter AF, Ackermans MT, Miedema F, Borghans JA, de Boer RJ, Tesselaar K (2012) Maintenance of peripheral naive $T$ cells is sustained by thymus output in mice but not humans. Immunity 36(2):288-297

147. Schatz DG, Swanson PC (2011) V(D)J recombination: mechanisms of initiation. Annu Rev Genet 45:167-202

148. Al-Harthi L, Marchetti G, Steffens CM, Poulin J, Sékaly R, Landay A (2000) Detection of T cell receptor circles (TRECs) as biomarkers for de novo $\mathrm{T}$ cell synthesis using a quantitative polymerase chain reaction-enzyme linked immunosorbent assay (PCR-ELISA). J Immunol Methods 237(1-2):187-197

149. Zhang SL, Bhandoola A (2012) Losing TREC with age. Immunity 36(2):163-165

150. Hug A, Korporal M, Schröder I, Haas J, Glatz K, StorchHagenlocher B, Wildemann B (2003) Thymic export function and $\mathrm{T}$ cell homeostasis in patients with relapsing remitting multiple sclerosis. J Immunol 171(1):432-437

151. Thewissen M, Linsen L, Somers V, Geusens P, Raus J, Stinissen P (2005) Premature immunosenescence in rheumatoid arthritis and multiple sclerosis patients. Ann N Y Acad Sci 1051:255-262

152. Duszczyszyn DA, Beck JD, Antel J, Bar-Or A, Lapierre Y, Gadag V, Haegert DG (2006) Altered naive CD4 and CD8 T cell homeostasis in patients with relapsing-remitting multiple sclerosis: thymic versus peripheral (non-thymic) mechanisms. Clin Exp Immunol 143(2):305-313

153. Thewissen M, Somers V, Venken K, Linsen L, van Paassen P, Geusens P, Damoiseaux J, Stinissen P (2007) Analyses of immunosenescent markers in patients with autoimmune disease. Clin Immunol 123(2):209-218

154. Puissant-Lubrano B, Viala F, Winterton P, Abbal M, Clanet M, Blancher A (2008) Thymic output and peripheral T lymphocyte 
subsets in relapsing-remitting multiple sclerosis patients treated or not by IFN-beta. J Neuroimmunol 193(1-2):188-194

155. Venken K, Hellings N, Broekmans T, Hensen K, Rummens JL, Stinissen P (2008) Natural naive CD4+CD25+ CD127low regulatory $\mathrm{T}$ cell (Treg) development and function are disturbed in multiple sclerosis patients: recovery of memory Treg homeostasis during disease progression. J Immunol 180(9):6411-6420

156. Chiarini M, Sottini A, Ghidini C, Zanotti C, Serana F, Rottoli M, Zaffaroni M, Bergamaschi R, Cordioli C, Capra R, Imberti L (2010) Renewal of the T-cell compartment in multiple sclerosis patients treated with glatiramer acetate. Mult Scler 16(2):218-227

157. Duszczyszyn DA, Williams JL, Mason H, Lapierre Y, Antel J, Haegert DG (2010) Thymic involution and proliferative T-cell responses in multiple sclerosis. J Neuroimmunol 221(1-2):73-80

158. Haegert DG, Hackenbroch JD, Duszczyszyn D, Fitz-Gerald L, Zastepa E, Mason H, Lapierre Y, Antel J, Bar-Or A (2011) Reduced thymic output and peripheral naïve CD4 T-cell alterations in primary progressive multiple sclerosis (PPMS). J Neuroimmunol 233(1-2):233-239

159. Zanotti C, Chiarini M, Serana F, Capra R, Rottoli M, Rovaris M, Cavaletti G, Clerici R, Rezzonico M, Caimi L, Imberti L (2011) Opposite effects of interferon- $\beta$ on new $B$ and $\mathrm{T}$ cell release from production sites in multiple sclerosis patients. $\mathrm{J}$ Neuroimmunol 240-241:147-150

160. Zanotti C, Chiarini M, Serana F, Sottini A, Garrafa E, Torri F, Caimi L, Rasia S, Capra R, Imberti L (2012) Peripheral accumulation of newly produced $\mathrm{T}$ and $\mathrm{B}$ lymphocytes in natalizumabtreated multiple sclerosis patients. Clin Immunol 145(1):19-26

161. Chiarini M, Sottini A, Bertoli D, Serana F, Caimi L, Rasia S, Capra R, Imberti L (2015) Newly produced T and B lymphocytes and $\mathrm{T}$-cell receptor repertoire diversity are reduced in peripheral blood of fingolimod-treated multiple sclerosis patients. Mult Scler 21(6):726-734

162. Hazenberg MD, Borghans JA, de Boer RJ, Miedema F (2003) Thymic output: a bad TREC record. Nat Immunol 4(2):97-99

163. Haas J, Fritzsching B, Trübswetter P, Korporal M, Milkova L, Fritz B, Vobis D, Krammer PH, Suri-Payer E, Wildemann B (2007) Prevalence of newly generated naive regulatory T cells (Treg) is critical for Treg suppressive function and determines Treg dysfunction in multiple sclerosis. J Immunol 179(2):13221330

164. Balint B, Haas J, Schwarz A, Jarius S, Fürwentsches A, Engelhardt K, Bussmann C, Ebinger F, Fritzsching B, Paul F, Seidel U, Vlaho S, Huppke P, Gärtner J, Wildemann B (2013) T-cell homeostasis in pediatric multiple sclerosis: old cells in young patients. Neurology 81(9):784-792

165. Broux B, Hellings N, Venken K, Rummens JL, Hensen K, Van Wijmeersch B, Stinissen P (2010) Haplotype 4 of the multiple sclerosis-associated interleukin-7 receptor alpha gene influences the frequency of recent thymic emigrants. Genes Immun 11(4): 326-333

166. Contin-Bordes C, Lazaro E, Richez C, Jacquemin C, Caubet O, Douchet I, Viallard J-F, Moreau J-F, Pellegrin J-L, Blanco P (2011) Expansion of myelin autoreactive CD8+ T lymphocytes in patients with neuropsychiatric systemic lupus erythematosus. Ann. Rheum. Dis. 70(5):868-871

167. Salou M, Garcia A, Michel L, Gainche-Salmon A, Loussouarn D, Nicol B, Guillot F, Hulin P, Nedellec S, Baron D, Ramstein G, Soulillou JP, Brouard S, Nicot AB, Degauque N, Laplaud DA (2015) Expanded CD8 T-cell sharing between periphery and CNS in multiple sclerosis. Ann Clin Transl Neurol 2(6):609-622

168. de Paula Alves Sousa A, Johnson KR, Nicholas R, Darko S, Price DA, Douek DC, Jacobson S, Muraro PA (2016) Intrathecal T-cell clonal expansions in patients with multiple sclerosis. Ann Clin Transl Neurol 3(6):422-433
169. Held K, Bhonsle-Deeng L, Siewert K, Sato W, Beltrán E, Schmidt S, Rühl G, Ng JK, Engerer P, Moser M, Klinkert WE, Babbe H, Misgeld T, Wekerle H, Laplaud DA, Hohlfeld R, Dornmair K (2015) $\alpha \beta$ T-cell receptors from multiple sclerosis brain lesions show MAIT cell-related features. Neurol Neuroimmunol Neuroinflamm 2(4):e107

170. Kanamori M, Watanabe S, Honma R, Kuroda M, Imai S, Takada K, Yamamoto N, Nishiyama Y, Kawaguchi Y (2004) EpsteinBarr virus nuclear antigen leader protein induces expression of thymus- and activation-regulated chemokine in B cells. J Virol 78(8):3984-3993

171. Hanabuchi S, Ito T, Park WR, Watanabe N, Shaw JL, Roman E, Arima K, Wang YH, Voo KS, Cao W, Liu YJ (2010) Thymic stromal lymphopoietin-activated plasmacytoid dendritic cells induce the generation of FOXP3 + regulatory T cells in human thymus. J Immunol 184(6):2999-3007

172. Ruland C, Renken H, Kuzmanov I, Fattahi Mehr A, Schwarte K, Cerina M, Herrmann A, Otte DM, Zimmer A, Schwab N, Meuth SG, Arolt V, Klotz L, Förster I, Scheu S, Alferink J (2017) Chemokine CCL17 is expressed by dendritic cells in the CNS during experimental autoimmune encephalomyelitis and promotes pathogenesis of disease. Brain Behav Immun 66:382-393

173. Scheu S, Ali S, Ruland C, Arolt V, Alferink J (2017) The C-C Chemokines CCL17 and CCL22 and Their Receptor CCR4 in CNS Autoimmunity. Int J Mol Sci 18(11):2306. https://doi.org/ 10.3390/ijms 18112306

174. Cavalcante P, Marcuzzo S, Franzi S, Galbardi B, Maggi L, Motta T, Ghislandi R, Buzzi A, Spinelli L, Novellino L, Baggi F, Antozzi C, Conforti F, De Pas TM, Barberis M, Bernasconi P, Mantegazza R (2017) Epstein-Barr virus in tumor-infiltrating B cells of myasthenia gravis thymoma: an innocent bystander or an autoimmunity mediator? Oncotarget 8(56):95432-95449

175. Meyer M, Höls A-K, Liersch B, Leistner R, Gellert K, Schalke B, Marx A, Niedobitek G (2011) Lack of evidence for Epstein-Barr virus infection in myasthenia gravis thymus. Ann Neurol 70(3): $515-518$

176. Kakalacheva K, Maurer MA, Tackenberg B, Munz C, Willcox N, Lunemann JD (2011) Intrathymic Epstein-Barr virus infection is not a prominent feature of myasthenia gravis. Ann Neurol 70(3): 508-514

177. Cavalcante P, Serafini B, Rosicarelli B, Maggi L, Barberis M, Antozzi C, Berrih-Aknin S, Bernasconi P, Aloisi F, Mantegazza $R$ (2010) Epstein-Barr virus persistence and reactivation in myasthenia gravis thymus. Ann Neurol 67(6):726-738

178. Munger KL, Levin LI, Hollis BW, Howard NS, Ascherio A (2006) Serum 25-hydroxyvitamin D levels and risk of multiple sclerosis. Jama 296(23):2832-2838

179. Ascherio A, Munger KL, Simon KC (2010) Vitamin D and multiple sclerosis. Lancet Neurol 9(6):599-612

180. Beal E (2011) High levels of maternal vitamin D may be protective against multiple sclerosis. Nat Rev Neurol 7(6):302

181. Mirzaei F, Michels KB, Munger K, O'Reilly E, Chitnis T, Forman MR, Giovannucci E, Rosner B, Ascherio A (2011) Gestational vitamin $\mathrm{D}$ and the risk of multiple sclerosis in offspring. Ann Neurol 70(1):30-40

182. Munger KL, Åivo J, Hongell K, Soilu-Hänninen M, Surcel HM, Ascherio A (2016) Vitamin D status during pregnancy and risk of multiple sclerosis in offspring of women in the Finnish Maternity Cohort. JAMA Neurol 73(5):515-519

183. Cyprian F, Lefkou E, Varoudi K, Girardi G (2019) Immunomodulatory effects of vitamin $\mathrm{D}$ in pregnancy and beyond. Front Immunol 10:2739

184. Willer CJ, Dyment DA, Sadovnick AD, Rothwell PM, Murray TJ, Ebers GC (2005) Timing of birth and risk of multiple sclerosis: population based study. BMJ 330(7483):120 
185. Wierzejska R, Jarosz M, Sawicki W, Bachanek M, SiubaStrzelińska M (2017) Vitamin D concentration in maternal and umbilical cord blood by season. Int J Environ Res Public Health 14(10):1121. https://doi.org/10.3390/ijerph14101121

186. Gur EB, Gur MS, Ince O, Kasap E, Genc M, Tatar S, Bugday S, Turan GA, Guclu S (2016) Vitamin D deficiency in pregnancy may affect fetal thymus development. Ginekol Pol 87(5):378-383

187. Mayan I, Somech R, Lev A, Cohen AH, Constantini NW, Dubnov-Raz G (2015) Thymus activity, vitamin D, and respiratory infections in adolescent swimmers. Isr Med Assoc J 17(9): $571-575$

188. Lamikanra AA, Tsang HP, Elsiddig S, Spencer M, Curnow E, Danby R, Roberts DJ (2020) The migratory properties and numbers of $\mathrm{T}$ regulatory cell subsets in circulation are differentially influenced by season and are associated with vitamin D status. Front Immunol 11:685

189. Disanto G, Watson CT, Meier UC, Ebers GC, Giovannoni G, Ramagopalan SV (2013) Month of birth and thymic output. JAMA Neurol 70(4):527-528

190. Dunn SE, Lee H, Pavri FR, Zhang MA (2015) Sex-based differences in multiple sclerosis (Part I): Biology of disease incidence. Curr Top Behav Neurosci 26:29-56

191. Zoller AL, Kersh GJ (2006) Estrogen induces thymic atrophy by eliminating early thymic progenitors and inhibiting proliferation of beta-selected thymocytes. J Immunol 176(12):7371-7378

192. Wang C, Dehghani B, Magrisso IJ, Rick EA, Bonhomme E, Cody DB, Elenich LA, Subramanian S, Murphy SJ, Kelly MJ, Rosenbaum JS, Vandenbark AA, Offner H (2008) GPR30 contributes to estrogen-induced thymic atrophy. Mol Endocrinol 22(3):636-648

193. Dragin N, Bismuth J, Cizeron-Clairac G, Biferi MG, Berthault C, Serraf A, Nottin R, Klatzmann D, Cumano A, Barkats M, Le Panse R, Berrih-Aknin S (2016) Estrogen-mediated downregulation of AIRE influences sexual dimorphism in autoimmune diseases. J Clin Invest 126(4):1525-1537

194. Bakhru P, Su MA (2016) Estrogen turns down "the AIRE". J Clin Invest 126(4):1239-1241

195. Berrih-Aknin S, Panse RL, Dragin N (2018) AIRE: a missing link to explain female susceptibility to autoimmune diseases. Ann N Y Acad Sci 1412(1):21-32

196. Zhu ML, Bakhru P, Conley B, Nelson JS, Free M, Martin A, Starmer J, Wilson EM, Su MA (2016) Sex bias in CNS autoimmune disease mediated by androgen control of autoimmune regulator. Nat Commun 7:11350

197. Degelman ML, Herman KM (2017) Smoking and multiple sclerosis: a systematic review and meta-analysis using the Bradford Hill criteria for causation. Mult Scler Relat Disord 17:207-216

198. Munger KL, Bentzen J, Laursen B, Stenager E, Koch-Henriksen N, Sørensen TI, Baker JL (2013) Childhood body mass index and multiple sclerosis risk: a long-term cohort study. Mult Scler 19(10):1323-1329

199. Zeyrek D, Ozturk E, Ozturk A, Cakmak A (2008) Decreased thymus size in full-term newborn infants of smoking mothers. Med Sci Monit 14(8):Cr423-Cr426

200. Qu W, Zhao WH, Wen X, Yan HY, Liu HX, Hou LF, Ping J (2019) Prenatal nicotine exposure induces thymic hypoplasia in mice offspring from neonatal to adulthood. Toxicol Lett 304:30 38

201. Araki T, Nishino M, Gao W, Dupuis J, Hunninghake GM, Murakami T, Washko GR, O'Connor GT, Hatabu H (2016) Normal thymus in adults: appearance on CT and associations with age, sex. BMI and smoking, Eur Radiol 26(1):15-24

202. Harrington KA, Kennedy DS, Tang B, Hickie C, Phelan E, Torreggiani W, Halpenny D (2018) Computed tomographic evaluation of the thymus-does obesity affect thymic fatty involution in a healthy young adult population? Br J Radiol 91(1089): 20170609

203. Olsson T, Barcellos LF, Alfredsson L (2017) Interactions between genetic, lifestyle and environmental risk factors for multiple sclerosis. Nat Rev Neurol 13(1):25-36

204. Romi F (2011) Thymoma in myasthenia gravis: from diagnosis to treatment. Autoimmune Dis 2011:474512

205. Bernard C, Frih H, Pasquet F, Kerever S, Jamilloux Y, Tronc F, Guibert B, Isaac S, Devouassoux M, Chalabreysse L, Broussolle C, Petiot P, Girard N, Sève P (2016) Thymoma associated with autoimmune diseases: 85 cases and literature review. Autoimmun Rev 15(1):82-92

206. Evoli A, Lancaster E (2014) Paraneoplastic disorders in thymoma patients. J Thorac Oncol 9(9 Suppl 2):S143-S147

207. Liu H, Edson RS (2019) Thymoma associated paraneoplastic encephalitis (TAPE), a potential cause of limbic encephalitis. BMJ Case Rep 12(8):e230709. https://doi.org/10.1136/bcr-2019230709

208. Ates MF, Sahin S, Cinar N, Bozdemir M, Karsidag S (2018) Thymoma and limbic encephalitis: a dangerous liaison. Prim Care Companion CNS Disord 20(5):17102257. https://doi.org/ 10.4088/PCC. 17102257

209. Aragaki M, Iimura Y, Teramoto K, Sato N, Hirose K, Hasegawa N (2015) Paraneoplastic extralimbic encephalitis associated with thymoma: a case report. Ann Thorac Cardiovasc Surg 21(4): 399-402

210. Tanaka H, Matsumura A, Okumura M, Kitaguchi M, Yamamoto S, Iuchi K (2005) Stiff man syndrome with thymoma. Ann Thorac Surg 80(2):739-741

211. Kosseifi SG, Mehta JB, Roy T, Byrd R Jr, Farrow J (2010) The occurrence of stiff person syndrome in a patient with thymoma: case report and literature review. Tenn Med 103(5):43-47

212. Kobayashi R, Kaji M, Horiuchi S, Miyahara N, Hino Y, Suemasu K (2014) Recurrent thymoma with stiff-person syndrome and pure red blood cell aplasia. Ann Thorac Surg 97(5):1802-1804

213. Wolfe GI, Kaminski HJ, Aban IB, Minisman G, Kuo HC, Marx A, Ströbel P, Mazia C, Oger J, Cea JG, Heckmann JM, Evoli A, Nix W, Ciafaloni E, Antonini G, Witoonpanich R, King JO, Beydoun SR, Chalk CH, Barboi AC, Amato AA, Shaibani AI, Katirji B, Lecky BR, Buckley C, Vincent A, Dias-Tosta E, Yoshikawa H, Waddington-Cruz M, Pulley MT, Rivner MH, Kostera-Pruszczyk A, Pascuzzi RM, Jackson CE, Ramos GSG, Verschuuren JJ, Massey JM, Kissel JT, Werneck LC, Benatar M, Barohn RJ, Tandan R, Mozaffar T, Conwit R, Odenkirchen J, Sonett JR, Jaretzki A 3rd, Newsom-Davis J, Cutter GR (2016) Randomized trial of thymectomy in myasthenia gravis. N Engl J Med 375(6): $511-522$

214. Leite MI, Coutinho E, Lana-Peixoto M, Apostolos S, Waters P, Sato D, Melamud L, Marta M, Graham A, Spillane J, Villa AM, Callegaro D, Santos E, da Silva AM, Jarius S, Howard R, Nakashima I, Giovannoni G, Buckley C, Hilton-Jones D, Vincent A, Palace J (2012) Myasthenia gravis and neuromyelitis optica spectrum disorder: a multicenter study of 16 patients. Neurology 78(20):1601-1607

215. Trotter JL, Clifford DB, Montgomery EB, Ferguson TB (1985) Thymectomy in multiple sclerosis: a 3-year follow-up. Neurology 35(7):1049-1051

216. Eskandari N, Mirmosayyeb O, Etemadifar M (2014) Effects of thymectomy on multiple sclerosis with myasthenia gravis. American Journal of Experimental and Clinical Research 1:60-63

217. Muraro PA, Douek DC, Packer A, Chung K, Guenaga FJ, Cassiani-Ingoni R, Campbell C, Memon S, Nagle JW, Hakim FT, Gress RE, McFarland HF, Burt RK, Martin R (2005) Thymic output generates a new and diverse TCR repertoire after autologous stem cell transplantation in multiple sclerosis patients. J Exp Med 201(5):805-816 
218. Darlington PJ, Touil T, Doucet JS, Gaucher D, Zeidan J, Gauchat D, Corsini R, Kim HJ, Duddy M, Jalili F, Arbour N, Kebir H, Chen J, Arnold DL, Bowman M, Antel J, Prat A, Freedman MS, Atkins H, Sekaly R, Cheynier R, Bar-Or A (2013) Diminished Th17 (not Th1) responses underlie multiple sclerosis disease abrogation after hematopoietic stem cell transplantation. Ann Neurol 73(3):341-354

219. Sun W, Popat U, Hutton G, Zang YC, Krance R, Carrum G, Land GA, Heslop H, Brenner M, Zhang JZ (2004) Characteristics of Tcell receptor repertoire and myelin-reactive $\mathrm{T}$ cells reconstituted from autologous haematopoietic stem-cell grafts in multiple sclerosis. Brain 127(Pt 5):996-1008

220. Burt RK, Loh Y, Cohen B, Stefoski D, Balabanov R, Katsamakis G, Oyama Y, Russell EJ, Stern J, Muraro P, Rose J, Testori A, Bucha J, Jovanovic B, Milanetti F, Storek J, Voltarelli JC, Burns WH (2009) Autologous non-myeloablative haemopoietic stem cell transplantation in relapsing-remitting multiple sclerosis: a phase I/II study. Lancet Neurol 8(3):244-253

221. Burt RK, Balabanov R, Han X, Sharrack B, Morgan A, Quigley K, Yaung K, Helenowski IB, Jovanovic B, Spahovic D, Arnautovic I, Lee DC, Benefield BC, Futterer S, Oliveira MC, Burman J (2015) Association of nonmyeloablative hematopoietic stem cell transplantation with neurological disability in patients with relapsing-remitting multiple sclerosis. Jama 313(3):275-284

222. Burt RK, Balabanov R, Burman J, Sharrack B, Snowden JA, Oliveira MC, Fagius J, Rose J, Nelson F, Barreira AA, Carlson K, Han X, Moraes D, Morgan A, Quigley K, Yaung K, Buckley $\mathrm{R}$, Alldredge C, Clendenan A, Calvario MA, Henry J, Jovanovic B, Helenowski IB (2019) Effect of nonmyeloablative hematopoietic stem cell transplantation vs continued disease-modifying therapy on disease progression in patients with relapsing-remitting multiple sclerosis: a randomized clinical trial. JAMA 321(2): $165-174$

223. Hendrawan K, Visweswaran M, Ma DDF, Moore JJ (2020) Tolerance regeneration by $\mathrm{T}$ regulatory cells in autologous haematopoietic stem cell transplantation for autoimmune diseases. Bone Marrow Transplant 55(5):857-866

224. Moore JB, Blanchard RK, Cousins RJ (2003) Dietary zinc modulates gene expression in murine thymus: results from a comprehensive differential display screening. Proc Natl Acad Sci U S A 100(7):3883-3888

225. Wong CP, Song Y, Elias VD, Magnusson KR, Ho E (2009) Zinc supplementation increases zinc status and thymopoiesis in aged mice. J Nutr 139(7):1393-1397

226. Xing Y, Smith MJ, Goetz CA, McElmurry RT, Parker SL, Min D, Hollander GA, Weinberg KI, Tolar J, Stefanski HE, Blazar BR (2018) Thymic epithelial cell support of thymopoiesis does not require Klotho. J Immunol 201(11):3320-3328

227. Jagannath VA, Filippini G, Di Pietrantonj C, Asokan GV, Robak EW, Whamond L, Robinson SA (2018) Vitamin D for the management of multiple sclerosis. Cochrane Database Syst Rev 9(9): Cd008422

228. Yang H, Youm YH, Vandanmagsar B, Rood J, Kumar KG, Butler AA, Dixit VD (2009) Obesity accelerates thymic aging. Blood 114(18):3803-3812

229. Dumont-Lagacé M, St-Pierre C, Perreault C (2015) Sex hormones have pervasive effects on thymic epithelial cells. Sci Rep 5:12895

230. Clise-Dwyer K, Huston GE, Buck AL, Duso DK, Swain SL (2007) Environmental and intrinsic factors lead to antigen unresponsiveness in CD4(+) recent thymic emigrants from aged mice. J Immunol 178(3):1321-1331

231. Inami Y, Yoshikai T, Ito S, Nishio N, Suzuki H, Sakurai H, Isobe K (2011) Differentiation of induced pluripotent stem cells to thymic epithelial cells by phenotype. Immunol Cell Biol 89(2): 314-321

232. Parent AV, Russ HA, Khan IS, LaFlam TN, Metzger TC, Anderson MS, Hebrok M (2013) Generation of functional thymic epithelium from human embryonic stem cells that supports host $\mathrm{T}$ cell development. Cell Stem Cell 13(2):219-229

233. Sun X, Xu J, Lu H, Liu W, Miao Z, Sui X, Liu H, Su L, Du W, He Q, Chen F, Shi Y, Deng H (2013) Directed differentiation of human embryonic stem cells into thymic epithelial progenitorlike cells reconstitutes the thymic microenvironment in vivo. Cell Stem Cell 13(2):230-236

234. Bortolomai I, Sandri M, Draghici E, Fontana E, Campodoni E, Marcovecchio GE, Ferrua F, Perani L, Spinelli A, Canu T, Catucci M, Di Tomaso T, Sergi Sergi L, Esposito A, Lombardo A, Naldini L, Tampieri A, Hollander GA, Villa A, Bosticardo M (2019) Gene modification and three-dimensional scaffolds as novel tools to allow the use of postnatal thymic epithelial cells for thymus regeneration approaches. Stem Cells Transl Med 8(10):1107-1122

235. Tajima A, Pradhan I, Trucco M, Fan Y (2016) Restoration of thymus function with bioengineered thymus organoids. Curr Stem Cell Rep 2(2):128-139

236. Seet CS, He C, Bethune MT, Li S, Chick B, Gschweng EH, Zhu Y, Kim K, Kohn DB, Baltimore D, Crooks GM, Montel-Hagen A (2017) Generation of mature T cells from human hematopoietic stem and progenitor cells in artificial thymic organoids. Nat Methods 14(5):521-530

237. Montel-Hagen A, Seet CS, Li S, Chick B, Zhu Y, Chang P, Tsai S, Sun V, Lopez S, Chen HC, He C, Chin CJ, Casero D, Crooks GM (2019) Organoid-induced differentiation of conventional T cells from human pluripotent stem cells. Cell Stem Cell 24(3):376389.e8

238. Chhatta AR, Cordes M, Hanegraaf MAJ, Vloemans S, Cupedo T, Cornelissen JJ, Carlotti F, Salvatori D, Pike-Overzet K, Fibbe WE, Hoeben RC, Mikkers HMM, Staal FJT (2019) De novo generation of a functional human thymus from induced pluripotent stem cells. J Allergy Clin Immunol 144(5):1416-1419.e7

239. Fan Y, Tajima A, Goh SK, Geng X, Gualtierotti G, Grupillo M, Coppola A, Bertera S, Rudert WA, Banerjee I, Bottino R, Trucco M (2015) Bioengineering thymus organoids to restore thymic function and induce donor-specific immune tolerance to allografts. Mol Ther 23(7):1262-1277

240. Su M, Lin Y, Cui C, Tian X, Lu X, He Z, Lai L (2017) ESCderived thymic epithelial cells expressing MOG prevents EAE by central and peripheral tolerance mechanisms. Cell Immunol 322: 84-91

241. Aslam B, Basit M, Nisar MA, Khurshid M, Rasool MH (2017) Proteomics: technologies and their applications. J Chromatogr Sci 55(2):182-196

242. Stubbington MJT, Lönnberg T, Proserpio V, Clare S, Speak AO, Dougan G, Teichmann SA (2016) T cell fate and clonality inference from single-cell transcriptomes. Nat Methods 13(4):329-332

243. Kula T, Dezfulian MH, Wang CI, Abdelfattah NS, Hartman ZC, Wucherpfennig KW, Lyerly HK, Elledge SJ (2019) T-Scan: a genome-wide method for the systematic discovery of $\mathrm{T}$ cell epitopes. Cell 178(4):1016-1028 e13

244. Schafflick D, Xu CA, Hartlehnert M, Cole M, SchulteMecklenbeck A, Lautwein T, Wolbert J, Heming M, Meuth SG, Kuhlmann T, Gross CC, Wiendl H, Yosef N, Meyer G, Horste Z (2020) Integrated single cell analysis of blood and cerebrospinal fluid leukocytes in multiple sclerosis. Nat Commun 11(1):247

Publisher's note Springer Nature remains neutral with regard to jurisdictional claims in published maps and institutional affiliations. 